\title{
Jointly Sponsored Research Program
}

\section{Annual Report January - December 1995}

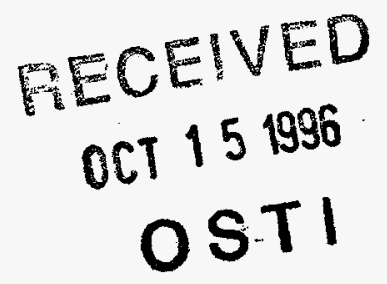

March 1996

Work Performed Under Contract No.: DE-FC21-93MC30098

For

U.S. Department of Energy

Office of Fossil Energy

Morgantown Energy Technology Center

Morgantown, West Virginia

By

University of North Dakota

Energy \& Environmental Research Center

P.O. Box 9018

Grand Forks, North Dakota 58202-9018

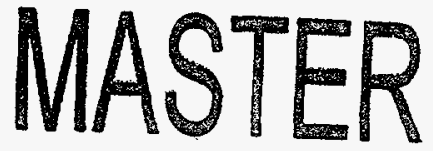

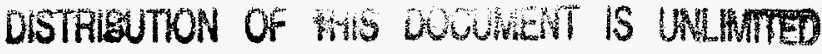




\section{Disclaimer}

This report was prepared as an account of work sponsored by an agency of the United States Government. Neither the United States Government nor any agency thereof, nor any of their employees, makes any warranty, express or implied, or assumes any legal liability or responsibility for the accuracy, completeness, or usefulness of any information, apparatus, product, or process disclosed, or represents that its use would not infringe privately owned rights. Reference herein to any specific commercial product, process, or service by trade name, trademark, manufacturer, or otherwise does not necessarily constitute or imply its endorsement, recommendation, or favoring by the United States Government or any agency thereof. The views and opinions of authors expressed herein do not necessarily state or reflect those of the United States Government or any agency thereof. 


\section{DISCLAIMER}

Portions of this document may be illegible in electronic image products. Images are produced from the best available original document. 


\title{
Jointly Sponsored Research Program
}

\author{
Annual Report \\ January - December 1995
}

Work Performed Under Contract No.: DE-FC21-93MC30098

\author{
For \\ U.S. Department of Energy \\ Office of Fossil Energy \\ Morgantown Energy Technology Center \\ P.O. Box 880 \\ Morgantown, West Virginia 26507-0880
}

By

University of North Dakota

Energy \& Environmental Research Center

P.O. Box 9018

Grand Forks, North Dakota 58202-9018 
SECTION A

\section{STATEMENT OF}

\section{TECHNICAL PROGRESS}




\section{SUMMARY OF ALL PROJECTS APPROVED FOR FUNDING}

UNDER COOPERATIVE AGREEMENT DE-FC21-93MC30098

\begin{tabular}{|c|c|c|c|c|c|c|c|}
\hline \multirow{3}{*}{$\begin{array}{l}\text { Task No. } \\
\text { Task } 1 \\
\end{array}$} & \multirow{3}{*}{$\begin{array}{c}\text { Title } \\
\text { Multiple-Use Marketing of Lignite }\end{array}$} & \multicolumn{4}{|c|}{ DOE Share } & \multirow{2}{*}{\multicolumn{2}{|c|}{$\begin{array}{l}\text { Cosponsor } \\
\text { Share }\end{array}$}} \\
\hline & & \multicolumn{2}{|c|}{ Prior Years } & \multicolumn{2}{|r|}{ FY95 } & & \\
\hline & & $\$$ & 20,000 & $\$$ & 0 & $\$$ & 20,000 \\
\hline Task 2 & Seventeenth Biennial Low-Rank Fuels Symposium & $\$$ & 35,000 & $\$$ & 0 & $\$$ & 35,000 \\
\hline Task 3 & $\begin{array}{l}\text { Slagging and Fouling Assessment of Coal and } \\
\text { Coal Chars }\end{array}$ & $\$$ & 15,175 & $\$$ & 0 & $\$$ & 15,175 \\
\hline Task 4 & $\begin{array}{l}\text { Chlorine Analysis and Removal from Products of } \\
\text { Thermally Recycled Plastics }\end{array}$ & $\$$ & 131,101 & $\$$ & 0 & $\$$ & 131,113 \\
\hline Task 5 & $\begin{array}{l}\text { Sorbent Regeneration from Circulating Fluidized- } \\
\text { Bed Combustors (FBCs) }\end{array}$ & $\$$ & 44,956 & $\$$ & 0 & $\$$ & 44,966 \\
\hline Task 7 & $\begin{array}{l}\text { Development of Methods to Predict } \\
\text { Agglomeration and Deposition in Fluidized-Bed } \\
\text { Combustors }\end{array}$ & $\$$ & 440,000 & $\$$ & 0 & $\$$ & 440,000 \\
\hline Task 8 & $\begin{array}{l}\text { Development of a Fireside Performance Index: } \\
\text { Convective Pass Fouling and Fly Ash } \\
\text { Collectibility }\end{array}$ & $\$$ & 370,000 & $\$$ & 0 & $\$$ & 370,000 \\
\hline Task 10 & $\begin{array}{l}\text { Timing of the Deposition of Uppermost } \\
\text { Cretaceous and Paleocene Coal-Bearing Deposits } \\
\text { in the Greater Glendive Area, Montana and North } \\
\text { Dakota }\end{array}$ & $\$$ & 33,980 & $\$$ & 0 & $\$$ & 33,980 \\
\hline Task 11 & Coal Agglomeration Consortium & $\$$ & 100,000 & $\$$ & 0 & $\$$ & 100,000 \\
\hline Task 13 & Phenol Purification Studies & $\$$ & 22,000 & $\$$ & 0 & $\$$ & 22,000 \\
\hline Task 14 & $\begin{array}{l}\text { Effect of Ethanol Denaturant on Gasoline Reid } \\
\text { Vapor Pressure }\end{array}$ & $\$$ & 49,978 & $\$$ & 0 & $\$$ & 49,981 \\
\hline Task 15 & $\begin{array}{l}\text { Process Development Unit Test Program for } \\
\text { Thermally Recycled Plastics }\end{array}$ & $\$$ & 630,000 & $\$$ & 0 & $\$$ & 809,120 \\
\hline Task 16 & $\begin{array}{l}\text { Bench-Scale Preparation and Combustion Testing } \\
\text { of Refuse-Derived Fuel-Coal Slurry Fuels }\end{array}$ & $\$$ & 95,000 & $\$$ & 0 & $\$$ & 135,000 \\
\hline Task 17 & Enhanced Air Toxics Control & $\$$ & 464,507 & $\$$ & 139,090 & $\$$ & 634,923 \\
\hline Task 18 & Coal Ash Resources Research Consortium & $\$$ & 115,000 & $\$$ & 83,900 & $\$$ & 268,350 \\
\hline Task 19 & $\begin{array}{l}\text { The Application of Fluidized-Bed Combustion } \\
\text { Residues for High-Volume Utilization Options }\end{array}$ & $\$$ & 160,000 & $\$$ & 0 & $\$$ & 160,000 \\
\hline Task 20 & $\begin{array}{l}\text { FT-IR Spectroscopic Investigation of Fireside } \\
\text { Deposits in a Pilot Plant Combustor }\end{array}$ & $\$$ & 45,000 & $\$$ & 0 & $\$$ & 45,000 \\
\hline Task 21 & $\begin{array}{l}\text { Sour Gas Plant Subsurface Remediation } \\
\text { Technology Research and Demonstration Project }\end{array}$ & $\$$ & 285,250 & $\$$ & 95,000 & $\$$ & 502,250 \\
\hline Task 22 & $\begin{array}{l}\text { Evaluation of Supercritical Fluid Extraction for } \\
\text { Analysis of Petroleum Industry Wastes }\end{array}$ & $\$$ & 100,000 & $\$$ & 0 & $\$$ & 100,000 \\
\hline
\end{tabular}




\begin{tabular}{|c|c|c|c|c|c|c|c|}
\hline \multirow[b]{2}{*}{ Task No. } & \multirow[b]{2}{*}{ Title } & \multicolumn{4}{|c|}{ DOE Share } & \multirow{2}{*}{\multicolumn{2}{|c|}{$\begin{array}{l}\text { Cosponsor } \\
\text { Share }\end{array}$}} \\
\hline & & \multicolumn{2}{|c|}{ Prior Years } & \multicolumn{2}{|r|}{ FY95 } & & \\
\hline Task 23 & Gas Industry Groundwater Research Program & $\$$ & 782,974 & $\$$ & 243,083 & \$ & $1,026,303$ \\
\hline Task 24 & $\begin{array}{l}\text { Utilization of Western Coals in Bituminous } \\
\text { Boilers - Pilot Plant Assessment of Blend } \\
\text { Properties and Their Impact on Critical Utility } \\
\text { Power Plant Components }\end{array}$ & $\$$ & 15,881 & $\$$ & 0 & $\$$ & 195,000 \\
\hline Task 25 & Physical Cleaning of Lignite & $\$$ & 30,000 & $\$$ & 0 & \$ & 30,000 \\
\hline Task 26 & $\begin{array}{l}\text { Remote-Site Power Generation Opportunities for } \\
\text { Alaska }\end{array}$ & $\$$ & 250,000 & $\$$ & 0 & $\$$ & 271,400 \\
\hline Task 27 & $\begin{array}{l}\text { Alaskan Low-Rank Coal-Water Fuel } \\
\text { Environmental Attributes and Combustion Test } \\
\text { Marketing }\end{array}$ & $\$$ & 50,000 & $\$$ & 0 & $\$$ & 62,000 \\
\hline Task 28 & $\begin{array}{l}\text { An Assessment of the Subsurface Fate of } \\
\text { Monoethanolamine at Sour Gas Processing Plant } \\
\text { Sites }\end{array}$ & $\$$ & 59,890 & $\$$ & 47,000 & $\$$ & 159,672 \\
\hline Task 29 & $\begin{array}{l}\text { Mitigation of Air Toxics from Lignite Generation } \\
\text { Facilities }\end{array}$ & $\$$ & 100,000 & $\$$ & 0 & $\$$ & 100,000 \\
\hline Task 30 & Hot-Gas Filter Ash Characterization Project & $\$$ & 230,000 & $\$$ & 320,000 & $\$$ & 670,000 \\
\hline Task 31 & $\begin{array}{l}\text { Formal Evaluation of Flue Gas Chemical } \\
\text { Measurement Methods Phase I - Verification of } \\
\text { Mercury Speciation by EPA (Draft) Method } 29\end{array}$ & $\$$ & 287,090 & $\$$ & 422,510 & $\$$ & $1,173,765$ \\
\hline Task 32 & $\begin{array}{l}\text { Organic Sulfur Removal from Coal with Super- } \\
\text { and Subcritical Water }\end{array}$ & $\$$ & 70,218 & $\$$ & 90,000 & $\$$ & 198,527 \\
\hline Task 33 & $\begin{array}{l}\text { Upgraded North Dakota Lignite - Production of } \\
\text { Test Quantities }\end{array}$ & $\$$ & 25,000 & $\$$ & 0 & $\$$ & 40,000 \\
\hline Task 34 & $\begin{array}{l}\text { Coal Quality Expert Fouling and Slagging } \\
\text { Algorithm Development }\end{array}$ & $\$$ & 40,000 & $\$$ & 0 & $\$$ & 60,000 \\
\hline Task 35 & $\begin{array}{l}\text { Evaluation of Field Analytical Techniques for } \\
\text { Mercury in Soil }\end{array}$ & $\$$ & 0 & $\$$ & 40,000 & $\$$ & 89,500 \\
\hline Task 36 & $\begin{array}{l}\text { Combustion Characterization of Carbonized RDF } \\
\text { from Temperature Optimization Tests }\end{array}$ & $\$$ & 0 & $\$$ & 200,000 & $\$$ & 304,096 \\
\hline Task 37 & $\begin{array}{l}\text { Recent Advances in Research on Ash Deposition } \\
\text { in Utility Boilers: Practical Applications for the } \\
\text { Electric Power and Coal Industries }\end{array}$ & $\$$ & 0 & $\$$ & 60,331 & $\$$ & 90,502 \\
\hline Task 38 & $\begin{array}{l}\text { Mercury Remediation Technology Research and } \\
\text { Demonstration }\end{array}$ & $\$$ & 0 & $\$$ & 40,000 & $\$$ & 60,500 \\
\hline Task 39 & $\begin{array}{l}\text { Preparation and Gasification of Thailand } \\
\text { Coal-Water Fuels }\end{array}$ & $\$$ & 0 & $\$$ & 49,771 & $\$$ & 75,000 \\
\hline Task 40 & Mercury Sorbent Evaluation & $\$$ & 0 & $\$$ & 60,350 & $\$$ & 89,650 \\
\hline
\end{tabular}


TABLE A-1 (continued)

\begin{tabular}{|c|c|c|c|c|c|}
\hline \multirow[b]{2}{*}{ Task No. } & \multirow[b]{2}{*}{ Title } & \multicolumn{2}{|c|}{ DOE Share } & \multirow{2}{*}{\multicolumn{2}{|c|}{$\begin{array}{l}\text { Cosponsor } \\
\text { Share }\end{array}$}} \\
\hline & & Prior Years & FY95 & & \\
\hline Task 41 & $\begin{array}{l}\text { Lignite Resource Characterization and Evaluation } \\
\text { for Mitigation of Ash Deposition }\end{array}$ & 0 & $\$ 152,000$ & \$ & 228,000 \\
\hline Task 42 & $\begin{array}{l}\text { Holocene Cyclicity in Western North } \\
\text { Dakota-Climate Change Interpreted from } \\
\text { Fluctuations in Alluvial Sedimentation }\end{array}$ & 0 & 64,972 & $\$$ & 99,964 \\
\hline Task 43 & $\begin{array}{l}\text { Oxidation of North Dakota Scrubber Sludge for } \\
\text { Soil Amendment and Production of Gypsum }\end{array}$ & 0 & $\$ 40,000$ & $\$$ & 80,000 \\
\hline Task 44 & Pilot Plant Assessment of Fly Ash Agglomeration & 0 & \$ 209,993 & $\$$ & 318,007 \\
\hline Task 45 & $\begin{array}{l}\text { Small-Scale Demonstration of the Freeze-Thaw } \\
\text { Evaporation Process to Treat Oil and Gas } \\
\text { Produced Waters }\end{array}$ & 0 & $\$ 200,000$ & $\$$ & 600,000 \\
\hline Total & & $\$ 5,098,000$ & $\$ 2,558,000$ & $\$$ & $9,938,744$ \\
\hline
\end{tabular}


PROJECT DESCRIPTIONS AND STATUS

\begin{tabular}{|c|c|c|c|}
\hline Task 1 & \multicolumn{2}{|c|}{ Multiple-Use Marketing of Lignite } & Status: Cor \\
\hline sors & \multicolumn{3}{|c|}{$\begin{array}{l}\text { Knife River Coal Mining Company; J.R. Simplot Company; North Dakota Industrial } \\
\text { Commission }\end{array}$} \\
\hline \multirow{2}{*}{\multicolumn{4}{|c|}{$\begin{array}{l}\text { Summary } \\
\text { The objective of this program was to provide a market feasibility study for the multiple uses of lignite in the city of } \\
\text { Grand Forks, North Dakota. Lignite and sulfur-capture additives were used to clean agriculture wastewater. Lignite } \\
\text { was also used after wastewater cleanup to generate steam and produce lignite briquettes. } \\
\text { Various combinations of lignite, waste lime sludge, lime, and an additive have been used to produce clear, essentially } \\
\text { odor-free water from potato wastewater. Collected residue containing starch material and lignite has been } \\
\text { successfully briquetted. A major expense in the upgrading of lignite (drying) is the capital and operating cost of dust- } \\
\text { handling equipment. Preliminary tests indicate these costs may be reduced by proper pretreatment of the coal. } \\
\text { Information has been collected on the economics of the multiple-use marketing of lignite used in cogeneration or } \\
\text { steam generation, wastewater cleaning, and/or briquettes, including possible waste solids disposal costs in Grand } \\
\text { Forks. The most environmentally acceptable coal-to-steam process is fluidized-bed combustion. No multiple-use } \\
\text { scheme was found that would make North Dakota lignites more economically acceptable than subbituminous coals. } \\
\text { The final report was issued in September } 1993 \text {. }\end{array}$}} \\
\hline & & & \\
\hline 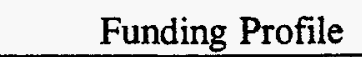 & DOE Share, $\$$ & 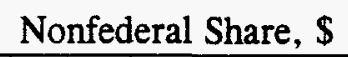 & \\
\hline & 20,000 & & \\
\hline
\end{tabular}

\begin{tabular}{|c|c|c|c|}
\hline Task 2 & \multicolumn{2}{|c|}{ Seventeenth Biennial Low-Rank Fuels Symposium } & Status: Complete \\
\hline Cosponsors & \multicolumn{3}{|c|}{$\begin{array}{l}\text { BNI Coal, Ltd.; Northern States Power Company; Minnesota Power; American Coal } \\
\text { Ash Association; N-R-G Energy, Inc.; Knife River Coal Mining Company; MDU } \\
\text { Resources Group, Inc.; Minnkota Power Cooperative, Inc.; North American Coal } \\
\text { Corporation; Otter Tail Power Company; Utility Fuels, Inc. }\end{array}$} \\
\hline \multirow{2}{*}{\multicolumn{4}{|c|}{$\begin{array}{l}\text { Summary } \\
\text { The goal of the Low-Rank Fuels Symposium is to provide a forum for industry, government, and academia to allow } \\
\text { the exchange of information that can be used to develop efficient technologies to utilize low-rank fuels in an } \\
\text { environmentally acceptable manner. } \\
\text { The symposium, held May 10-13,1993, in St. Louis, Missouri, was organized in a manner to provide for the } \\
\text { discussion, communication, and dissemination of recent information on low-rank fuel utilization. Participants in the } \\
\text { symposium consisted of a multidisciplinary blend of representatives from industry, research organizations, } \\
\text { government agencies, and universities. The conference proceedings were issued in May 1994. }\end{array}$}} \\
\hline & & & \\
\hline Fun & DOE Share, \$ & Nonfederal Sh & \\
\hline FY93 & 35,000 & 35,000 & \\
\hline
\end{tabular}


PROJECT DESCRIPTIONS AND STATUS

\begin{tabular}{|c|c|c|c|}
\hline Task 3 & \multicolumn{2}{|c|}{ Slagging and Fouling Assessment of Coal and Coal Chars } & Status: Complete \\
\hline Cosponsor & \multicolumn{3}{|c|}{ Illinois State Geological Survey } \\
\hline \multicolumn{4}{|c|}{$\begin{array}{l}\text { Summary } \\
\text { Eastern utility boilers now firing high-sulfur, high-volatile bituminous Illinois coal must consider alternatives to meet } \\
\text { the } 1995 \text { emission guidelines of } 2.5 \mathrm{lb} \text { of } \mathrm{SO}_{2} / \mathrm{MMBtu} \text {. Alternatives include coal switching, blending coals, or } \\
\text { retrofitting with costly scrubbers. Another alternative is to use a low-sulfur char produced from the mild gasification } \\
\text { of Illinois coal and subsequent low-temperature oxidation of the char. This char could be burned exclusively or } \\
\text { blended with the parent coal to reduce emissions. } \\
\text { An Illinois Basin coal and two coal-char blends were submitted by the Illinois State Geological Survey for evaluation } \\
\text { of their fouling and slagging propensity. Laboratory tests and calculations indicated that one blend, prepared from } \\
\text { char produced under high-temperature conditions with the addition of hydrated lime, would cause severe slagging, } \\
\text { high-temperature fouling, and, possibly, low-temperature fouling problems. The second blend, prepared from char } \\
\text { produced under low-temperature conditions, exhibited slagging and fouling behavior similar to the Illinois coal itself } \\
\text { and is seen as an attractive feedstock because of a lower sulfur content and higher Btu content than the parent coal. } \\
\text { All laboratory testing, analysis, and interpretation of the results have been completed. The final report for the project } \\
\text { was submitted to the Illinois State Geological Survey (ISGS) and to the U.S. Department of Energy in September } \\
1993 \text {. }\end{array}$} \\
\hline Funding Profile & & & \\
\hline FY93 & 15,175 & 15,175 & \\
\hline
\end{tabular}


PROJECT DESCRIPTIONS AND STATUS

\begin{tabular}{|c|c|c|c|}
\hline Task 4 & \multicolumn{2}{|c|}{$\begin{array}{l}\text { Chlorine Analysis and Removal from Products of } \\
\text { Thermally Recycled Plastics }\end{array}$} & Status: Complete \\
\hline Cosponsor & \multicolumn{3}{|c|}{ American Plastics Council and 3M Company } \\
\hline \multicolumn{4}{|c|}{$\begin{array}{l}\text { Summary } \\
\text { Plastics account for nearly } 20 \% \text {, by volume, of the material entering a landfill. Public pressures to recycle products } \\
\text { and, correspondingly, to reduce the amount of material landfilled have prompted investigation of practicable means } \\
\text { of plastics recycling. Some plastics (e.g., high-density polyethylene [HDPE]) are easily isolated and recycled by } \\
\text { existing mechanical methods. Other types are difficult to recycle by traditional methods for a variety of reasons. } \\
\text { Thermal depolymerization, or thermal cracking, breaks down plastics to liquids and gaseous products similar to the } \\
\text { petroleum-based starting materials used in plastics manufacturing. These products are then reintroduced to a } \\
\text { petroleum refinery, where they will be used for new plastics production and for the production of other petroleum } \\
\text { products. }\end{array}$} \\
\hline \multicolumn{4}{|c|}{$\begin{array}{l}\text { A key aspect of any plastics recycling process is the removal of chlorine, present primarily from polyvinyl chloride } \\
\text { (PVC). All currently envisioned end uses for recycled plastics have tolerance levels for chlorine. Earlier work at the } \\
\text { Energy \& Environmental Research Center using sorbents for chlorine capture in the process was very successful. } \\
\text { This program examined the potential for using a postreactor fixed sorbent bed for chlorine removal from } \\
\text { postconsumer plastics. Variables investigated included fixed-bed temperature, sorbent particle size, and chlorine } \\
\text { loading. In addition to the fixed-bed study, an analytical development effort was completed, which examined the } \\
\text { detection limits and accuracy of the gas chromatograph-atomic emission detector (GC-AED) technique used at the } \\
\text { Energy \& Environmental Research Center to quantitate organic chlorine content of the product liquids. Analysis of } \\
\text { the liquids indicated total organic chlorine could be reduced to } 20 \text { ppm with a feed stream of } 2 \%-5 \% \text { PVC, which } \\
\text { was the goal of the program. The final report was submitted in December } 1994 \text {. }\end{array}$} \\
\hline Fundin & DUE S & Noille & \\
\hline & & & \\
\hline
\end{tabular}


PROJECT DESCRIPTIONS AND STATUS

\begin{tabular}{|c|c|c|c|}
\hline Task 5 & \multicolumn{2}{|c|}{$\begin{array}{l}\text { Sorbent Regeneration from Circulating Fluidized-Bed } \\
\text { Combustors (FBCs) }\end{array}$} & Status: Complete \\
\hline Cosponsor & \multicolumn{3}{|c|}{ Community Energy Alternatives Inc. } \\
\hline \multicolumn{4}{|c|}{$\begin{array}{l}\text { Summary } \\
\text { Circulating fluidized-bed combustion (CFBC) is an efficient method for burning high-sulfur fuels to meet stringent } \\
\mathrm{SO}_{2} \text { emission level requirements. One concern when high-sulfur coal is burned is the high usage of limestone and, } \\
\text { consequently, the relatively large amounts of solid waste for disposal. The large amount of limestone is a result of } \\
\text { utilizing only } 30 \%-50 \% \text { of the available calcium in a once-through system. In this project, a sorbent regenerator was } \\
\text { coupled with the Energy \& Environmental Research Center CFBC pilot plant system to study the regeneration and } \\
\text { recycling of the spent sorbent. }\end{array}$} \\
\hline \multicolumn{4}{|c|}{$\begin{array}{l}\text { The first series of combustion tests has been completed on the Energy \& Environmental Research Center pilot-scale } \\
\text { circulating fluidized-bed combustor. During this testing, the performance of pelletized fly ash from the baghouse of a } \\
\text { full-scale circulating fluidized-bed combustor was compared to that of fresh limestone. Based on these results, the } \\
\text { limestone feed and subsequent solid waste disposal could be reduced by approximately } 25 \% \text { with pelletization and } \\
\text { recycle of the fly ash alone. }\end{array}$} \\
\hline \multirow{2}{*}{\multicolumn{4}{|c|}{$\begin{array}{l}\text { Further testing coupling the fly ash pelletization with the regeneration of the bottom ash resulted in limestone usage } \\
\text { being reduced by a maximum of } 84.5 \% \text {. There appears to be significant potential for better optimizing and } \\
\text { integrating the operations of the fly ash pelletization and the bottom ash regeneration processes with the circulating } \\
\text { fluidized-bed combustor operation to meet the original goal of a greater than } 90 \% \text { reduction in limestone usage. This } \\
\text { would likely require some detailed bench-scale studies of the pelletization and regeneration processes before } \\
\text { proceeding with further pilot-scale testing. }\end{array}$}} \\
\hline & & & \\
\hline Funding Profile & DOE Share, $\$$ & Nonfederal Share, $\$$ & \\
\hline FY93 & 44,956 & 44,966 & \\
\hline
\end{tabular}


PROJECT DESCRIPTIONS AND STATUS

\begin{tabular}{|c|c|c|c|}
\hline Task 7 & \multicolumn{2}{|c|}{$\begin{array}{l}\text { Development of Methods to Predict Agglomeration and } \\
\text { Deposition in Fluidized-Bed Combustors (FBCs) }\end{array}$} & Status: Ongoing \\
\hline Cosponsors & \multicolumn{3}{|c|}{$\begin{array}{l}\text { Ahlstrom Pyropower, Inc.; Riley Stoker Corporation; Northern States Power } \\
\text { Company; Electric Power Research Institute; North Dakota Industrial Commission }\end{array}$} \\
\hline \multirow{2}{*}{\multicolumn{4}{|c|}{$\begin{array}{l}\text { Summary } \\
\text { The focus of this project is to develop a method to predict agglomeration and deposition in fluidized-bed combustors } \\
\text { (FBCs). The basic mechanisms of agglomeration and deposition have been developed from the detailed analysis } \\
\text { performed on samples from the Montana-Dakota Utilities' Heskett Station and Northern States Power Black Dog } \\
\text { Station. A simple model based on ash chemistry has been developed that may be able to predict agglomerating } \\
\text { tendencies. } \\
\text { The bench-scale test matrix, in which operating conditions, sorbent type, and additives were varied, has been } \\
\text { completed. The data from these tests are being incorporated into the agglomeration mechanisms. The testing has } \\
\text { identified a number of bed material/sorbents that greatly reduce the agglomeration tendency. }\end{array}$}} \\
\hline & & & \\
\hline \multicolumn{4}{|c|}{$\begin{array}{l}\text { A computer model designed to predict deposition in pulverized coal-fired units is being adapted to predict deposition } \\
\text { in FBCs. Using the information generated from the full-scale and bench-scale systems, combined with work on the } \\
\text { fundamental chemistry and physics of the deposited materials, methods for predicting the onset of deposition and } \\
\text { agglomeration, and possible mitigating measures will be developed during the remainder of the project. }\end{array}$} \\
\hline \multicolumn{4}{|c|}{ project will be completed February 1996.} \\
\hline Funding Profile & DOE Share, \$ & Nonfederal Share, \$ & \\
\hline FY93 & 240,000 & 240,000 & \\
\hline FY94 & 200,000 & 200,000 & \\
\hline
\end{tabular}




\begin{tabular}{|c|c|c|c|}
\hline Task 8 & \multicolumn{2}{|c|}{$\begin{array}{l}\text { Development of a Fireside Performance Index: } \\
\text { Convective Pass Fouling and Fly Ash Collectibility }\end{array}$} & Status: Ongoing \\
\hline Cosponsors & \multicolumn{3}{|c|}{$\begin{array}{l}\text { Northern States Power Company; Minnesota Power; Electric Power Research Institute; } \\
\text { Union Electric, Inc.; Kansas City Power \& Light }\end{array}$} \\
\hline \multirow{2}{*}{\multicolumn{4}{|c|}{$\begin{array}{l}\text { Summary } \\
\text { A performance index to provide utilities and coal companies with a quick method to assess coal performance has been } \\
\text { developed. Work began on the project in October } 1992 \text { and was completed by July } 31,1995 \text {. } \\
\text { Work has been completed using a drop-tube furnace for the purpose of carrying out bench-scale fouling and slagging } \\
\text { combustion tests to refine existing fouling and slagging indices that are based on computer-controlled scanning } \\
\text { electron microscopy. Four field tests were conducted at Union Electric's Labadie Station, Minnesota Power's Clay } \\
\text { Boswell Station, Northern States Power's Sherburne County Station, and Kansas City Power \& Light's Iatan and } \\
\text { Hawthorn Stations to verify the performance indices. Mineralogical data and other pertinent information obtained for } \\
\text { over } 50 \text { different coals were used to develop the performance indices. Final algorithms were developed and } \\
\text { packaged as a software product for predicting low-temperature fouling, high-temperature fouling, slagging, slag } \\
\text { tapping, grindability, ash erosion, ash collectibility-opacity, and sootblowing indices using the coal database and the } \\
\text { empirical combustion performance information from the laboratory and the field. Beta versions of the software were } \\
\text { sent out in February } 1995 \text { and a final version of the software was distributed, along with a training seminar, in June } \\
\text { 1995. }\end{array}$}} \\
\hline & & & \\
\hline \multicolumn{4}{|c|}{$\begin{array}{l}\text { A report summarizing the first phase of the work was submitted to the sponsor in July } 1993 \text {. A final draft topical } \\
\text { report was completed in November } 1995 \text { that details the work performed during the second phase of the project, as } \\
\text { well as comprehensive results for the entire duration of the project. After comments have been received, the final } \\
\text { version of the topical report will be sent out along with a finalized and updated first version of the software. }\end{array}$} \\
\hline Tuning 1 ive & are, $\$$ & 180140, & \\
\hline FY93 & 160,000 & 160,000 & \\
\hline FY94 & 210,000 & 210,000 & \\
\hline
\end{tabular}


PROJECT DESCRIPTIONS AND STATUS

\begin{tabular}{|l|l|l|}
\hline Task 10 & $\begin{array}{l}\text { Timing of the Deposition of Uppermost Cretaceous and } \\
\text { Paleocene Coal-Bearing Deposits in the Greater Glendive } \\
\text { Area, Montana and North Dakota }\end{array}$ & Status: Ongoing \\
\hline The Research Foundation of the State University of New York at Stony Brook; \\
National Geographic Society
\end{tabular}


PROJECT DESCRIPTIONS AND STATUS

\begin{tabular}{|c|c|c|c|}
\hline Task 11 & \multicolumn{2}{|c|}{ Coal Agglomeration Consortium } & $\begin{array}{l}\text { Status: Negotiating with } \\
\text { commercial sponsors }\end{array}$ \\
\hline Cosponsor & \multicolumn{3}{|c|}{$\begin{array}{l}\text { Bennett Industries of Alabama, Inc.; Custom Coals Corporation; North American Coal; } \\
\text { BNI Coal }\end{array}$} \\
\hline \multirow{2}{*}{\multicolumn{4}{|c|}{$\begin{array}{l}\text { Summary } \\
\text { The Energy \& Environmental Research Center has developed a prospectus for a Coal Agglomeration Consortium in } \\
\text { order to advance briquetting and other agglomeration technologies. It aims to provide cost-effective methods to } \\
\text { produce strong, stable, and high-performance compacts, having an increased value from high-rank coal fines or low- } \\
\text { rank coal. Binders, other additives including organic waste (e.g., biomass) materials, and key aggregating machines } \\
\text { will be examined. The consortium direction and work plan will each have major contributions from the sponsors of } \\
\text { the consortium. } \\
\text { The overall objective is to develop new briquetting technologies to produce coal briquettes that will achieve } \\
\text { environmental compliance. The specific aims are to 1) conduct briquette formulation tests on a minimum of four } \\
\text { coals per year selected by consortium members; 2) evaluate the strength, stability, and combustion/gasification } \\
\text { reactivity of the briquettes; } 3 \text { ) begin developing correlations between fundamental coal properties and briquetting } \\
\text { parameters; and 4) perform an economic assessment of briquetting processes. A work plan will be determined at the } \\
\text { first and subsequent meetings of the sponsors. }\end{array}$}} \\
\hline & & & \\
\hline \multicolumn{4}{|c|}{$s$ been shown in the consortium, but companies are } \\
\hline Funding Profile & DOE Share, \$ & Nonfederal Share, \$ & \\
\hline FY93 & 100,000 & 100,000 & \\
\hline
\end{tabular}

\begin{tabular}{|l|l|l|}
\hline Task 13 & Phenol Purification Studies & Status: Complete \\
\hline Cosponsor & Dakota Gasification Company (DGC) & \\
\hline
\end{tabular}

Summary

Phenolics are major liquid products obtained during the gasification of coals. Unfortunately they are not recovered as pure compounds, but contain a wide range of contaminants, including neutral oils and basic nitrogen compounds. On the open market, the cost and purity of the phenol dictate the marketability of the product. Dakota Gasification Company has a strong interest in reducing the cost of upgrading to produce purer phenol that can be more readily marketed. The Energy \& Environmental Research Center performed tests on a number of possible purification methods and parametric studies on methods that showed promise. Selected catalysts would destroy certain reactive impurities but at the expense of producing higher-molecular-weight polymers. The project was completed and final report was submitted in October 1994.

\begin{tabular}{|c|c|c|}
\hline Funding Profile & DOE Share, $\$$ & Nonfederal Share, $\$$ \\
\hline FY93 & 22,000 & 22,000 \\
\hline
\end{tabular}


PROJECT DESCRIPTIONS AND STATUS

\begin{tabular}{|c|c|c|c|}
\hline Task 14 & \multicolumn{2}{|c|}{$\begin{array}{l}\text { Effect of Ethanol Denaturant on Gasoline Reid Vapor } \\
\text { Pressure }\end{array}$} & Status: Complete \\
\hline Cosponsor & \multicolumn{3}{|c|}{ National Corn Growers Association } \\
\hline \multicolumn{4}{|c|}{$\begin{array}{l}\text { Summary } \\
\text { The mainstay of current ethanol utilization is as an oxygen additive and octane enhancer for gasoline. The significant } \\
\text { reduction in carbon monoxide emissions by the use of oxygenated fuels has won wide support for the practice of } \\
\text { oxygen addition to gasoline. As attention is brought to bear on other air pollutants, particularly oxides of nitrogen } \\
\left(\mathrm{NO}_{\mathrm{x}} \text { ), the benefits of ethanol have been questioned. }\right.\end{array}$} \\
\hline \multicolumn{4}{|c|}{$\begin{array}{l}\text { It is commonly accepted that when ethanol is added to a gasoline, the Reid vapor pressure (RVP) of the feedstock } \\
\text { fuel is increased. For a } 10 \% \text { ethanol-blended fuel (E10), this increase is usually reported as } 1 \text { pound per square inch. } \\
\text { The tendency of ethanol to increase RVP has caused it to be labeled by some as a polluting fuel. The U.S. } \\
\text { Environmental Protection Agency has proposed to control } \mathrm{NO}_{x} \text { emissions by reducing RVP and capping oxygen } \\
\text { levels. }\end{array}$} \\
\hline \multicolumn{4}{|c|}{$\begin{array}{l}\text { Following established laboratory protocols, in all nine cases where water was added to an E10 blend, RVP increased. } \\
\text { Additionally, the four ethanol denaturants studied produced significantly different final RVPs. It can be concluded } \\
\text { that the RVP increase currently attributed to ethanol may be an ethanol-denaturant-water effect. This possibility } \\
\text { increases the strategies to reduce the RVP of E10 blends. A nontechnical final report has been completed, issued, } \\
\text { and approved by sponsors. }\end{array}$} \\
\hline Funding Profile & DOE Share, \$ & Nonfederal Share, $\$$ & \\
\hline FY93 & 49,978 & 49,981 & \\
\hline
\end{tabular}




\begin{tabular}{|l|l|l|}
\hline Task 15 & $\begin{array}{l}\text { Process Development Unit Test Program for Thermally } \\
\text { Recycled Plastics }\end{array}$ & Status: Ongoing \\
\hline Cosponsor & The American Plastics Council \\
\hline
\end{tabular}

Summary

Plastics account for nearly $20 \%$ by volume of the material entering a landfill. Public pressures to recycle products and, correspondingly, to reduce the amount of material landfilled, have prompted investigation of practicable means of plastics recycling. Some plastics (e.g., high-density polyethylene [HDPE]) are easily isolated and recycled by existing mechanical methods. Other types are difficult to recycle by traditional methods for various reasons. Thermal depolymerization, or thermal cracking, breaks down plastics to liquid and gaseous products similar to the petroleum-based starting materials used in plastics manufacturing. These products are then reintroduced to a petroleum refinery, where they will be used for new plastics production and for the production of other petroleum products.

A year-long scoping study of the thermal depolymerization characteristics of several plastics typically found in postconsumer streams has recently been completed at the Energy \& Environmental Research Center (EERC). Because of the success of this program, a scale-up program was funded, whose purpose was to evaluate the viability of a commercial-scale thermal depolymerization process. This evaluation was based upon a series of tests using the EERC's 100-lb/hr fluid-bed process development unit (PDU). Goals of the program include the generation of liquid and gaseous products for end-user evaluation and familiarity with and the collection of product yield data and of scalable engineering data. The data can be used to perform an economic assessment of the process. Tests conducted in the PDU indicated liquid yields from postconsumer plastics similar to those seen in bench-scale tests. Bench-scale tests were also conducted to determine olefin versus liquid yields. Testing has been completed.

Liquid products have been characterized and were determined to be an acceptable refinery feedstock. All process streams have been analyzed and found to be nonhazardous. Results from the product characterizations were presented in a workshop involving officials from U.S. Environmental Protection Agency headquarters, the state of North Dakota, local municipalities, and industries. Results from the bench-scale testing indicate that olefin yields coupled with olefin prices appear to make a more attractive option over liquid production in locations where an olefin plant is located.

Other results indicated the most important process conditions in order of importance are temperature, gas residence time, bed material, and solids residence time. Sufficient data have been produced to perform a detailed commercial economic and process design.

A final report on the PDU Test program will be available in the fourth quarter of 1995. A draft of the report has been completed and will be available in December.

Three additional tasks have been added to the program. These include upgrades to the PDU, creating a database for accessing general test information, and writing a comprehensive summary of the work that has been funded by the APC, 3M, and the U.S. Department of Energy. This will include a summary of liquid production, olefin production, terepthalic and benzoic acid production, and chlorine capture.

\begin{tabular}{|c|c|c|}
\hline Funding Profile & DOE Share, $\$$ & Nonfederal Share, $\$$ \\
\hline FY93 & 250,000 & 250,000 \\
\hline FY94 & 380,000 & 559,120 \\
\hline
\end{tabular}




\begin{tabular}{|l|l|l|}
\hline Task 16 & $\begin{array}{l}\text { Bench-Scale Preparation and Combustion Pressure of } \\
\text { Refuse-Derived Fuel-Coal Slurry Fuels }\end{array}$ & Status: Complete \\
\hline Cosponsor & EnerTech Environmental, Inc. \\
\hline
\end{tabular}

\section{Summary}

As public concern grows and government regulations become increasingly strict, numerous municipalities and industries face exorbitant costs for solid waste disposal that run head-on into bottom-line profits. Concurrently, markets for lignite coal have been limited primarily because of its high moisture content, which results in a low heating value per unit weight and high transportation costs per unit energy. In addition, most of the North Dakota lignite reserves have sulfur contents that exceed the Clean Air Act Amendments Phase II emission limits for power plants of $1.2 \mathrm{lb} \mathrm{SO}_{2}$ per MMBtu. EnerTech Environmental, Inc., and the Energy \& Environmental Research Center have developed a slurry carbonization technology that efficiently converts low-sulfur solid waste materials such as municipal solid waste, municipal sludge, and pulp and paper sludge into clean, homogeneous, high-energy slurry fuels. The goal of blending the solid waste with lignite was to reduce the $\mathrm{SO}_{2}$ emissions from combustion of the carbonized slurry fuel and also to provide a much better means of utilizing the potential energy from the solid waste.

The objective of this research program was to assess the feasibility of blending RDF with a lignite coal and thermally treating the mixture in an aqueous phase (slurry carbonization). Batch slurry carbonization experiments were conducted with three different slurries: a RDF slurry, a North Dakota lignite slurry, and a blend of North Dakota lignite and RDF. After the slurry carbonization treatment, all three slurries were concentrated and combusted in a bench-scale pressurized fluidized-bed combustion (PFBC) unit.

Slurry performance tests conducted on the feed and carbonized RDF slurry indicated an increase in solids loading, from 10 to over $45 \mathrm{wt} \%$ solids. In addition, chloride concentrations were reduced by over $80 \mathrm{wt} \%$ in the carbonized RDF slurry. Slurry carbonization studies for lignite indicated that the slurry heating value was increased by over $60 \%$, with an achievable solids concentration over $55 \mathrm{wt} \%$. Also, sulfur concentrations were reduced from 1.8 to $1.3 \mathrm{wt} \%$ (moisture-free) for the carbonized lignite slurry. Results from the blended carbonized RDF and lignite slurry indicated a compliance fuel that could be slurried to approximately $57 \mathrm{wt} \%$, a $220 \%$ increase in energy density. PFBC combustion results indicated that all three fuels obtained excellent combustion efficiencies, exceeding $99.0 \%$. Sulfur dioxide emissions were significantly lower for the carbonized RDF slurry $(0.10 \mathrm{lb} / \mathrm{MMBtu})$ than for the carbonized lignite slurry (0.62 lb/MMBtu). A final report was issued in November 1994.

\begin{tabular}{|c|c|c|}
\hline Funding Profile & DOE Share, \$ & Nonfederal Share, \$ \\
\hline FY93 & 75,000 & 75,000 \\
\hline FY94 & 20,000 & 60,000 \\
\hline
\end{tabular}


PROJECT DESCRIPTIONS AND STATUS

\begin{tabular}{|c|c|c|c|}
\hline Task 17 & \multicolumn{2}{|c|}{ Enhanced Air Toxics Control } & Status: Ongoing \\
\hline Cosponsor & \multicolumn{3}{|c|}{ Electric Power Research Institute } \\
\hline \multicolumn{4}{|c|}{$\begin{array}{l}\text { Summary } \\
\text { The primary goal of this project is to determine the potential to control air toxic emissions in conventional particulate } \\
\text { control devices. Since many of the toxic heavy metals are more concentrated in fine fly ash particles, a method of } \\
\text { superior control of these air toxic emissions is simply to collect them in a particulate control device. For elements } \\
\text { that are entirely in the solid state, effective control is dependent on achieving a high collection efficiency for the } \\
\text { particle sizes where the air toxic elements are primarily concentrated. In the case of volatile elements, such as } \\
\text { mercury, effective control may depend greater on the surface adsorption properties of the fly ash or added sorbents. } \\
\text { Introduction of small amounts of a high-surface-area material, such as activated carbon, ahead of a particulate control } \\
\text { device may provide effective mercury control. Parametric pilot tests were conducted, evaluating independent } \\
\text { variables such as sorbent type, sorbent concentration, temperature, coal type, and particulate control method. } \\
\text { Task } 6 \text { was added to the project in March } 1995 \text {, extending the project duration by } 9 \text { months. The objective of Task } 6 \\
\text { is to determine the effect of mercury and chlorine spiking on mercury speciation and sorbent effectiveness. The } \\
\text { Electric Power Research Institute has granted a no-cost extension to the project to facilitate further funding. The new } \\
\text { completion date is June } 30,1996 \text {. An interim report is being compiled at this time. Future work will focus on pilot- } \\
\text { scale tests and the effects of process conditions on mercury sorbent effectiveness. The exact nature of the tests will } \\
\text { depend on the results from bench-scale tests. }\end{array}$} \\
\hline Funding Profile & DOE Share, $\$$ & Nonfederal Share, $\$$ & \\
\hline FY93 & 257,907 & & \\
\hline FY94 & 206,600 & 206,600 & \\
\hline FY95 & 139,090 & 170,000 & \\
\hline
\end{tabular}


PROJECT DESCRIPTIONS AND STATUS

\begin{tabular}{|c|c|c|c|}
\hline Task 18 & \multicolumn{2}{|c|}{ Coal Ash Resources Research Consortium (CARRC) } & Status: Ongoing \\
\hline Cosponsors & \multicolumn{3}{|c|}{$\begin{array}{l}\text { Otter Tail Power Company; Cooperative Power; Contech-J.W. Brett, Inc.; Northern } \\
\text { States Power Company; National Minerals Corporation }\end{array}$} \\
\hline \multicolumn{4}{|c|}{$\begin{array}{l}\text { Summary } \\
\text { CARRC performs research on coal by-products, with emphasis on the scientific understanding of the behavior of } \\
\text { these materials in utilization applications and various disposal conditions. } \\
\text { The primary goal of CARRC is to work with industry to solve ash-related problems and promote the environmentally } \\
\text { safe, economical utilization and disposal of these highly complex materials. Secondary goals include the generation } \\
\text { of scientific and engineering information regarding regulations and specifications for coal combustion fly ash, the } \\
\text { development of improved characterization methods for coal by-products, the demonstration of new or improved coal } \\
\text { ash use applications, and technology commercialization. }\end{array}$} \\
\hline \multicolumn{4}{|c|}{$\begin{array}{l}\text { The Coal Ash Properties Database has been updated with leaching and computer-controlled scanning electron } \\
\text { microscopy (CCSEM) results, as well as standard test results from fly ash samples submitted through the year. A } \\
\text { laboratory procedure for determining the rate of heat of hydration was developed and applied to several coal fly ash } \\
\text { samples. Results of the heat of hydration procedure are under evaluation. Cluster analysis was performed on results } \\
\text { of CCSEM. Ternary diagrams developed using CCSEM and clustering results are being used to determine relative } \\
\text { cementitious properties of coal fly ash and to predict expected hydration reaction. Laboratory testing of high-volume } \\
\text { fly ash concrete was performed to evaluate durability and strength. CARRC researchers also helped in development } \\
\text { of an American Society for Testing and Materials standard guideline for the use of coal fly ash structural fill. }\end{array}$} \\
\hline \multicolumn{4}{|c|}{$\begin{array}{l}\text { This year's CARRC activities include demonstration-scale and commercial coal ash utilization projects, which } \\
\text { potentially include the construction of sidewalks, parking lots, curbs and gutters, dumpster pads, and parking lot } \\
\text { barriers. Other research areas include the quantitation of coal ash reactivity, behavior of coal ash in products, } \\
\text { environmental evaluation of coal ash and coal ash products, and the maintenance and expansion of the coal ash } \\
\text { properties database. }\end{array}$} \\
\hline Funding Profile & DOE Share, \$ & Nonfederal Share, \$ & \\
\hline FY93 & 70,000 & 70 & \\
\hline FY94 & 45,000 & 70,000 & \\
\hline FY95 & 00 & 12 & \\
\hline
\end{tabular}


PROJECT DESCRIPTIONS AND STATUS

\begin{tabular}{|c|c|c|c|}
\hline Task 19 & \multicolumn{2}{|c|}{$\begin{array}{l}\text { The Application of Fluidized-Bed Combustion Residues } \\
\text { for High-Volume Utilization Options }\end{array}$} & Status: To be canceled \\
\hline \multicolumn{4}{|l|}{ Cosponsors } \\
\hline \multicolumn{4}{|c|}{$\begin{array}{l}\text { Summary } \\
\text { Large volumes of residual bed material and fly ash are barriers to commercialization of advanced fluidized-bed } \\
\text { combustion (FBC) technologies and contribute to the nation's growing solid waste problems. Utilization options can } \\
\text { be identified and demonstrated to make these FBC residues commercially marketable. Since a wide range of FBC } \\
\text { residues and related end-use products can be produced from different fuels and processing conditions, it will be } \\
\text { advantageous to investigate a variety of these materials for physical, chemical, mineralogical, and environmental } \\
\text { characteristics. By employing a combined materials science and engineering approach, the University of North } \\
\text { Dakota Energy \& Environmental Research Center was to move the investigation beyond the largely empirical } \\
\text { approach used in most past projects to enhance utilization options for FBC residuals. We believe that a greatly } \\
\text { increased understanding of the materials and processes involved is vital to identify and demonstrate realistic } \\
\text { utilization options that are technically, economically, and environmentally feasible under institutional and regulatory } \\
\text { constraints applying in the real world. }\end{array}$} \\
\hline \multicolumn{4}{|c|}{$\begin{array}{l}\text { Unfortunately, after submitting this project to the U.S. Department of Energy, the Energy \& Environmental Research } \\
\text { Center was unable to attract sufficient nonfederal funding to match U.S. Department of Energy funds. As a result, } \\
\text { this project will be canceled, and the U.S. Department of Energy funds will be used to fund an alternate project. }\end{array}$} \\
\hline Funding Profile & DOE Share, \$ & Jonfederal Share, \$ & \\
\hline FY93 & 160,000 & 160,000 & \\
\hline
\end{tabular}




\begin{tabular}{|c|c|c|c|}
\hline Task 20 & \multicolumn{2}{|c|}{$\begin{array}{l}\text { FT-IR Spectroscopic Investigation of Fireside Deposits in } \\
\text { a Pilot Plant Combustor }\end{array}$} & Status: Complete \\
\hline Cosponsor & \multicolumn{3}{|c|}{ Electric Power Research Institute } \\
\hline \multicolumn{4}{|c|}{$\begin{array}{l}\text { Summary } \\
\text { Successful operation of current, as well as advanced, coal combustion systems depends on controlling and minimizing } \\
\text { the development of ash fouling and slagging, i.e., fireside deposits. The development of these deposits depends not } \\
\text { only on the combustion design and operating conditions, but also on the composition and quantity of the inorganic } \\
\text { species in the coal. The increasing demand for control and mitigation of ash deposition in combustion boilers } \\
\text { necessitates refined and advanced technologies. To optimize control strategies, a distinct need exists to obtain } \\
\text { improved and faster identification of imminent ash deposition. New advanced spectroscopic techniques offer the } \\
\text { potential to achieve this goal. } \\
\text { An accessory for a Fourier transform infrared (FT-IR) spectrometer was designed to monitor deposit formation in the } \\
\text { convective pass of a pilot-scale combustor. The accessory, the infrared emission sampling probe (IESP), provides a } \\
\text { means to monitor infrared emissions produced inside the furnace duct. The probe is designed to fit into a standard } \\
\text { optical access while still providing operator viewing through the port. }\end{array}$} \\
\hline \multirow{2}{*}{\multicolumn{4}{|c|}{$\begin{array}{l}\text { Tests involving the collection of emission spectra of ash deposits on the furnace duct and deposition probes under } \\
\text { coal-fired operating conditions of the combustor were conducted on two coals using the IESP. The IR monitoring } \\
\text { ash deposits was evaluated using Antelope subbituminous and Illinois No. } 6 \text { bituminous coals. } \\
\text { Data collected using the IESP indicate that the current instrument configuration offers promise in application as a } \\
\text { deposit thickness monitor. No information was obtainable on deposit chemistry during formation using this } \\
\text { configuration of the IESP; however, several improvements in the instrument can be made that will make it more } \\
\text { effective in the measurement of deposit chemistry. }\end{array}$}} \\
\hline & & & \\
\hline \multicolumn{4}{|c|}{$\begin{array}{l}\text { The capability of FT-IR for remotely monitoring deposit thickness has been demonstrated. After some refinement of } \\
\text { the optical interface and development of turnkey software, further investigation of the infrared emissions of ash } \\
\text { deposits can be done. The development of the FT-IR technique coupled with the IESP can be continued to advance } \\
\text { capabilities for the determination of deposit chemistries in situ. }\end{array}$} \\
\hline \multirow{2}{*}{\multicolumn{4}{|c|}{$\begin{array}{l}\text { In addition, for the application of remote IR measurements to deposit thickness, a s } \\
\text { developed using the concept of a two-wavelength measurement. The new instrume } \\
\text { to construct and operate than an FT-IR spectrometer. A unit could be built as a han } \\
\text { pyrometer. } \\
\text { This project is complete and the final report will be submitted in December } 1995 \text {. }\end{array}$}} \\
\hline & & & \\
\hline Funding Profile & DOE Share, \$ & Nonfederal Share, $\$$ & \\
\hline FY93 & 45,000 & 45,000 & \\
\hline
\end{tabular}


PROJECT DESCRIPTIONS AND STATUS

\begin{tabular}{|l|l|l|}
\hline Task 21 & $\begin{array}{l}\text { Sour Gas Plant Subsurface Remediation Technology } \\
\text { Research and Demonstration Project }\end{array}$ & Status: Ongoing \\
\hline Cosponsor & Canadian Association of Petroleum Producers \\
\hline
\end{tabular}

\section{Summary}

This project involves a number if interdependent research components related to the development and/or application of remediation technologies to address soil and groundwater contamination at natural gas processing facilities.

Continuing research activities include a pilot-scale evaluation of bioventing to assess its potential in cold climates, a pilot-scale evaluation of ex situ bioremediation of groundwater, and a prototype field demonstration of freeze crystallization for the remediation of contaminated groundwater. New activities involve the evaluation of air sparging to address in situ bioremediation of volatile organic compounds from both groundwater and the vadose zone.

Bioventing trials have indicated a relatively high degree of bioactivity, as measured by oxygen depletion in the subsurface, throughout the colder months when subsurface temperatures have dropped to as low as $4^{\circ} \mathrm{C}$. Observed oxygen depletion rates have been decreasing with time, suggesting the removal of hydrocarbon contaminants.

Confirmatory subsurface sampling and analysis are scheduled for the last quarter of 1996.

Ex situ bioremediation of groundwater was discontinued in October 1995 due to inclement (freezing) weather. At the time of shutdown, the levels of benzene, toluene, ethylbenzene, and total xylenes were all being reduced to less than $1 \mu \mathrm{g} / \mathrm{L}$. However, nitrification was not apparent at the colder temperatures $\left(2^{\circ} \mathrm{C}\right)$ observed in the recirculating water. System operation will be reestablished in the spring of 1996.

Freeze crystallization field testing was postponed because of subcontractor scheduling conflicts and will be conducted at the gas plant site in the spring of 1996.

An evaluation of air sparging will be conducted during the winter, spring, and early summer of 1996 . Sparging trials will be conducted using a series of vertical wells rather than a single horizontal well, because of the excessive costs estimated to successfully install a horizontal well in the gravel and cobbles in the subsurface at the gas plant site.

\begin{tabular}{|c|c|c|}
\hline Funding Profile & DOE Share, $\$$ & Nonfederal Share, \$ \\
\hline FY93 & 131,250 & 131,250 \\
\hline FY94 & 154,000 & 231,000 \\
\hline FY95 & 95,000 & 140,000 \\
\hline
\end{tabular}


PROJECT DESCRIPTIONS AND STATUS

\begin{tabular}{|c|c|c|c|}
\hline Task 22 & \multicolumn{2}{|c|}{$\begin{array}{l}\text { Evaluation of Supercritical Fluid Extraction for Analysis } \\
\text { of Petroleum Industry Wastes }\end{array}$} & Status: Complete \\
\hline Cosponsor & \multicolumn{3}{|c|}{ American Petroleum Institute (API) } \\
\hline \multicolumn{4}{|c|}{$\begin{array}{l}\text { Summary } \\
\text { A previous joint venture project with API was completed in March 1993. The first project investigated using } \\
\text { supercritical fluid extraction (SFE) to extract gasoline and diesel-range hydrocarbons from soils and included a } \\
\text { successful field demonstration of the technique. Extraction of pollutants from waste petroleum sludges and } \\
\text { preliminary investigations to define "quantitative" extractions for complex samples were performed. The results of } \\
\text { these studies were sufficiently encouraging that a second project with API was started in March } 1993 \text { to develop on- } \\
\text { line methods for BTEX (benzene, toluene, ethylbenzene, and xylene) determinations as well as to extend SFE } \\
\text { methods to heavier hydrocarbons. }\end{array}$} \\
\hline \multicolumn{4}{|c|}{$\begin{array}{l}\text { A number of publications were produced to summarize the methods developed and analytical results from the project. } \\
\text { General categories of activities and advances include total petroleum hydrocarbons (TPH) and BTEX determinations } \\
\text { in the gasoline and diesel range; TPH determinations for heavy hydrocarbons and polycyclic aromatic hydrocarbons } \\
\text { (PAH), including fuel evaluations; and theoretical factors controlling "quantitative" aspects of SFE. Methods } \\
\text { developed include SFE coupled with gas chromatography (GC), SFE-infrared (SFE-IR) spectrometry, SFE with } \\
\text { carbon dioxide and oxyonic modifiers, quantitative SFE methods, and use of drying agents. }\end{array}$} \\
\hline \multicolumn{4}{|c|}{ The project final report was submitted in August 1994.} \\
\hline Funding Profile & DOE Share, \$ & Nonfederal Share, $\$$ & \\
\hline FY93 & 50,000 & 50,000 & \\
\hline FY94 & 50,000 & 50,000 & \\
\hline
\end{tabular}


PROJECT DESCRIPTIONS AND STATUS

\begin{tabular}{|c|c|c|c|}
\hline Task 23 & \multicolumn{2}{|c|}{ Gas Industry Groundwater Research Program } & Status: Ongoing \\
\hline Cosponsor & \multicolumn{3}{|l|}{ Gas Research Institute } \\
\hline \multicolumn{4}{|c|}{$\begin{array}{l}\text { Summary } \\
\text { The objectives of this research program are to develop a comprehensive study to evaluate soil and groundwater } \\
\text { contamination at natural gas industry sites and to assess cleanup options. Years } 1 \text { and } 2 \text { of the program focused on } \\
\text { the collection and assessment of background information and data necessary to conduct long-term laboratory and field } \\
\text { studies. Year } 3 \text { activities included the instrumentation of four gas industry field study sites in New Mexico and } \\
\text { Pennsylvania and associated laboratory studies. Contamination from elemental mercury has been the focus of these } \\
\text { initial field and laboratory studies. During Year } 4 \text {, two additional mercury field sites were instrumented in } \\
\text { Louisiana. Four quarters of groundwater sampling were completed during Year } 5 \text {. A total of fourteen GRI topical } \\
\text { reports have been published, including eight which are related to mercury. In addition, a risk-based screening model } \\
\text { (HgSCREEN }{ }^{\mathrm{TM}} \text { ) was developed for prioritizing sites for mercury remediation. During Year } 6 \text {, a workshop focused } \\
\text { on mercury contamination at oil and gas industry sites was held, in New Orleans, Pittsburgh, and San Diego. A total } \\
\text { of } 145 \text { attendees included representatives from the energy industry, regulatory agencies, environmental consulting } \\
\text { firms, and universities. } \\
\text { The focus of the program has shifted from mercury to other contaminants at gas industry facilities, such as glycols } \\
\text { and amines. It is anticipated that this effort will continue for several years and will include a major effort addressing } \\
\text { the remediation of sites contaminated from past practices. }\end{array}$} \\
\hline Funding Profile & DOE Share, $\$$ & Nonfederal & \\
\hline FY93 & 499,994 & 500,00 & \\
\hline FY94 & 282,980 & 400,00 & \\
\hline FY95 & 243,083 & 126,30 & \\
\hline
\end{tabular}




\begin{tabular}{|l|l|l|}
\hline Task 24 & $\begin{array}{l}\text { Utilization of Western Coals in Bituminous Boilers - Pilot } \\
\text { Plant Assessment of Blend Properties and Their Impact on } \\
\text { Critical Utility Power Plant Components }\end{array}$ & Complete \\
\hline Cosponsors & $\begin{array}{l}\text { Electric Power Research Institute; Consol; Empire State Electric Energy Research } \\
\text { Corporation; Ziegler Coal Company }\end{array}$ \\
\hline
\end{tabular}

\section{Summary}

The objective of this program was to assess the impact on boiler performance of blending eastern and western coals.

Flame stability testing, high-temperature $\left(2000^{\circ}\right.$ and $\left.2200^{\circ} \mathrm{F}\right)$ fouling tests, and low-temperature $\left(1500^{\circ} \mathrm{F}\right)$ fouling tests were completed for two subbituminous coals and one bituminous coal. Mill performance tests, performed by Consol, Inc., were also completed. The final project report was submitted in December 1994.

Results indicate that blending of Powder River Basin (PRB) coals with bituminous coals is an effective strategy for reducing $\mathrm{SO}_{2}$ emissions from pulverized coal-fired boilers. The presence of the subbituminous coal will result in a number of operational impacts to a bituminous-design boiler. Mill testing indicated thermal load derates between $25 \%$ and $55 \%$ of the maximum input of bituminous coal when the higher-moisture subbituminous coals are ground. High-temperature and low-temperature fouling of boiler heat-transfer surfaces can also be expected to increase as the percentage of PRB coal in the blend is increased; conversely, levels of unburned carbon may be expected to decrease. This was confirmed during flame stability testing, which indicated as good or better flame stability as the percentage of PRB in the blend was increased.

\begin{tabular}{|c|c|c|}
\hline Funding Profile & DOE Share, \$ & Nonfederal Share, \$ \\
\hline FY93 & 15,881 & 195,000 \\
\hline
\end{tabular}

\begin{tabular}{|l|l|l|}
\hline Task 25 & Physical Cleaning of Lignite & Status: Complete \\
\hline Cosponsors & Knife River Coal Mining Company; North Dakota Industrial Commission \\
\hline
\end{tabular}

\section{Summary}

The purpose of this study was to elucidate the feasibility for producing from select North Dakota lignites a stable lump fuel with reduced sulfur, moisture, and sodium oxide contents. For this study, a single North Dakota lignite was crushed, sized, and then treated by bench-scale washability testing. The reduction of sulfur and inorganic contents as a function of coal size was estimated for commercial physical cleaning methods. The sized coal was also subjected to a novel water classification process to separate clean coal from inorganic-laden coal fines. Ion exchange using carbonated water (carbonic acid) was investigated as a method for reducing the coal sodium content to improve fouling characteristics. Commercial dry coal-cleaning methods, such a high-gradient magnetic separation, were investigated for sulfur reduction using various coal size fractions. An EERC-developed oil agglomeration process was investigated for selective rejection of minerals from fine lignite coal ( -100 mesh) and as a method to aggregate fine coal produced during water classification experiments. Pellets were prepared using conventional binders or novel binders, e.g., coal gasification-derived tar oil. A recommendation was prepared concerning the processing methodology required to produce larger quantities of lump fuel.

This study demonstrated that lignite could be physically cleaned to reduce ash content from 9 to 6 wt $\%$ moisture-free and sulfur emissions from 2.0 to $0.9 \mathrm{lb} \mathrm{SO}_{2} / \mathrm{MM} \mathrm{Btu}$. Low-moisture briquettes with heating values near $10,000 \mathrm{Btu} / \mathrm{lb}$ were successfully produced using low-cost waste wheat and newspaper binders. A final report was submitted to the sponsors in September 1994.

\begin{tabular}{|c|c|c|}
\hline Funding Profile & DOE Share, $\$$ & Nonfederal Share, $\$$ \\
\hline FY93 & 30,000 & 30,000 \\
\hline
\end{tabular}




\begin{tabular}{|c|c|c|c|}
\hline Tas & \multicolumn{2}{|c|}{ Remote-Site Power Generation Opportunities for Alaska } & Status: Ongoing \\
\hline & \multicolumn{3}{|c|}{$\begin{array}{l}\text { Alaska Science \& Technology Foundation; Usibeli Coal Mine, Inc.; Placer Dome U.S. } \\
\text { Inc.; ENPAC Energy Pacific Company; Major International; Power Engineers; } \\
\text { International Coal Preparation Consultants Limited; University of Alaska Fairbanks }\end{array}$} \\
\hline \multirow{2}{*}{\multicolumn{4}{|c|}{$\begin{array}{l}\text { E) together with the Alaska Division of Energy (ADE) and a number of the } \\
\text { project to develop alternative small-scale power generation technology options } \\
\text { tlaska. The Energy \& Environmental Research Center (EERC) is working with } \\
\text { ology Center (METC) to assess options for using the tremendous reserves of } \\
\text { scale power units. } \\
\text { ase diesel generators fueled with expensive fuel oil for electricity production. } \\
\text { ka is heavily subsidized by the state through the Power Cost Equalization } \\
\text { out } \$ 20 \text { million annually. Fuel oil is used extensively for residential and public } \\
\text { ivity will be to reduce the use of fuel oil in Alaskan villages by developing } \\
\text { lications. }\end{array}$}} \\
\hline & & & \\
\hline \multicolumn{4}{|c|}{$\begin{array}{l}\text { in Anchorage, Alaska, in May } 1994 \text { as a first step in the } \\
\text { throughout the state. The workshop was a success: it } \\
\text { ent policy makers, suppliers of technology, and end } \\
\text { sentations and breakout discussion groups during the } \\
\text { aber of technology options were offered that could meet }\end{array}$} \\
\hline \multicolumn{4}{|c|}{$\begin{array}{l}\text { A second workshop was held in Seattle, WA, in Sept } \\
\text { the energy needs of remote villages in Alaska. Addit } \\
\text { commercialize the technologies and transfer the infor }\end{array}$} \\
\hline \multicolumn{4}{|r|}{$\begin{array}{l}\text { onal Affairs, Doyon, } \\
\text { on. }\end{array}$} \\
\hline 10 (1) & & & \\
\hline & & & \\
\hline
\end{tabular}


PROJECT DESCRIPTIONS AND STATUS

\begin{tabular}{|c|c|c|c|}
\hline Task 27 & \multicolumn{2}{|c|}{$\begin{array}{l}\text { Alaskan Low-Rank Coal-Water Fuel Environmental } \\
\text { Attributes and Combustion Test Marketing }\end{array}$} & Status: Ongoing \\
\hline Cosponsor & \multicolumn{3}{|c|}{ Alaska Division of Energy (ADE) } \\
\hline \multicolumn{4}{|c|}{$\begin{array}{l}\text { Summary } \\
\text { This work is proposed as a means to expedite a project to demonstrate at a commercial scale the production and } \\
\text { utilization of coal-water fuel (CWF) made from hot-water-dried Alaskan subbituminous coal. Its objectives include } \\
\text { developing low-rank coal-water fuel (LRCWF) combustion test programs with selected potential end users, defining } \\
\text { the environmental benefits of replacing heavy oil with CWF, and updating the marketing video prepared with the } \\
\text { Alaska Energy Authority, now the Division of Energy. The work plan was completed and approved in October } \\
\text { 1995. A final report and other deliverables will be sent to DOE in December } 1995 \text {. }\end{array}$} \\
\hline Funding Profile & DOE Share, $\$$ & Nonfederal Share, $\$$ & \\
\hline FY94 & 50,000 & 62,000 & \\
\hline
\end{tabular}


PROJECT DESCRIPTIONS AND STATUS

\begin{tabular}{|l|l|l|}
\hline Task 28 & $\begin{array}{l}\text { An Assessment of the Subsurface Fate of } \\
\text { Monoethanolamine at Sour Gas Processing Plant Sites }\end{array}$ & Status: Ongoing \\
\hline Cosponsor & $\begin{array}{l}\text { Canadian Association of Petroleum Producers, Canadian Occidental Petroleum Ltd., } \\
\text { Environment Canada, National Energy Board (Canada) (other cosponsors are being } \\
\text { sought) }\end{array}$ \\
\hline
\end{tabular}

\section{Summary}

Monoethanolamine (MEA) is one of the most commonly used chemicals for the removal of hydrogen sulfide, carbon dioxide, and other acid gases from the natural gas in which they occur. At gas processing plants that use alkanolamines for acid gas removal, spills and the on-site management of wastes containing alkanolamines and their thermal reaction products have commonly resulted in subsurface contamination that is the focus of some environmental concern. This project is investigating the natural attenuation processes that control the fate of MEA.

Project activities have thus far accomplished the following:

- Series of samples for project activities has been obtained from a presently inactive sour gas processing plant site in Alberta.

- Experiments designed to determine the effects of temperature and concentration of MEA on the rate of MEA biodegradation in soil/sediment have been completed.

- Experiments designed to estimate the biodegradability of organic compounds in soil/sediment exposed to MEA-containing "sweetening" wastes have been completed.

- Experiments designed to determine whether high concentrations of MEA are toxic or inhibitory to microorganisms in soil/sediment have been completed.

- Experiments designed to estimate the biodegradeability of MEA under anaerobic conditions have been completed.

- Experiments designed to assess the role of interactions between MEA and soil/sediment by the determination of distribution coefficients $\left(\mathrm{K}_{\mathrm{d}}\right.$ values) have been completed.

- Available ion chromatography (IC) capabilities have been adapted for the quantitation of MEA in liquids at levels down to $10 \mathrm{ppb}$. Some work has also been done on adapting these capabilities for the quantitation of MEA thermal reaction products in liquids at ppm levels.

- An effective method for the extraction of MEA from soil, sediment, and solid experimental residues for IC analysis has been developed.

- A joint effort with the National Hydrology Research Institute to examine the use of IC and liquid chromatography/mass spectometry methods for the detailed analysis of MEA and MEA-related compounds in selected liquid samples has been completed.

- The final report on the experimental activities completed thus far is in the process of being finalized.

- Selected analytical support has been provided to other investigators that are more comprehensively evaluating the toxic effects of subsurface contaminants at the noted sour gas processing plant site.

- Experiments designed to estimate the biodegradability of an apparently recalcitrant fraction of organic nitrogenous compounds are under way.

- The experimental design has been completed for an assessment of the biodegradability of selected MEA-related thermal reaction products.

- The experimental design has been completed for a preliminary evaluation of the effectiveness of landfarming as a remediation technique for soils/sediments with MEA-related contamination.

\begin{tabular}{|c|c|c|}
\hline Funding Profile & DOE Share, \$ & Nonfederal Share, \$ \\
\hline FY94 & 59,890 & 89,672 \\
\hline FY95 & 47,000 & 70,000 \\
\hline
\end{tabular}




\begin{tabular}{|l|l|l|}
\hline Task 29 & $\begin{array}{l}\text { Mitigation of Air Toxics from Lignite Generation } \\
\text { Facilities }\end{array}$ & Status: Complete \\
\hline Cosponsor & $\begin{array}{l}\text { Lignite Research Council; Electric Power Research Institute (EPRI); Montana-Dakota } \\
\text { Utilities Company; Minnesota Power; Basin Electric Power Cooperative; Cooperative } \\
\text { Power Association }\end{array}$ \\
\hline
\end{tabular}

Summary

Concerns over emissions of trace metals, considered air toxics, from coal-fired power plants are increasing. The Amendments to the Clean Air Act of 1990 list 189 substances as potential hazardous air pollutants. Further, the Amendments established a schedule under which the U.S. Environmental Protection Agency (EPA) is required to establish maximum achievable control technology standards for existing major sources of hazardous pollutants. A major source is any source that emits (or has the potential to emit) more than 10 tons per year of any one listed pollutant, or 25 tons per year or more of any combination of listed pollutants. Coal combustion is thought to be a significant source for eleven metals on the list of 189 substances (antimony, arsenic, beryllium, cadmium, chromium, cobalt, lead, manganese, mercury, nickel, and selenium).

The purpose of this project is to determine the applicability of using sorbents to control the emissions of trace elements during the combustion of lignite and Powder River Basin (PRB) coals. Research activities performed under this project will supplement and complement other research projects currently under way at the Energy \& Environmental Research Center.

The Big Sky PRB coal was analyzed using atomic absorption (AA) and inductively coupled argon plasma spectroscopy (ICAP) to determine the concentrations of antimony, arsenic, beryllium, cadmium, chromium, cobalt, lead, manganese, mercury, nickel, and selenium. Along with the trace element analysis, standard bulk chemistry analyses were performed.

Lime and activated carbon-based sorbents were selected for testing based on results from a complementary project currently funded by EPA, the North Dakota Industrial Commission, and industry. The selected precombustion (lime) and postcombustion (activated carbon) sorbents were tested separately in a pilot-scale $550,000-\mathrm{Btu} / \mathrm{hr}$ particulate test combustor (PTC) equipped with an electrostatic precipitator and baghouse. Both particulate and gas samples were obtained during the tests to determine their trace element contents. Particulate and gas samples were collected and analyzed using currently accepted EPA methods. Results from the PTC testing were compiled to determine the reduction in trace element emissions as a result of the mitigation technologies tested. Most of the trace elements, with the exception of $\mathrm{Hg}$ and $\mathrm{Se}$, were in the solid phase and collected in the baghouse. Precombustion and postcombustion sorbents do not appear to be effective for comparing $\mathrm{Hg}$ or Se. The ashes from the tests were tested for their leachability, which may impact their potential disposal. The pre- and postcombustion sorbents tested do not appear to have any detrimental effect of ash utilization and disposal.

A final report was completed and submitted to DOE in October 1995.

\begin{tabular}{|c|c|c|c|}
\hline Funding Profile & DOE Share, $\$$ & Nonfederal Share, $\$$ & \\
\hline FY94 & 100,000 & 100,000 & \\
\hline
\end{tabular}




\begin{tabular}{|c|c|c|c|}
\hline Task & \multicolumn{2}{|c|}{ Hot-Gas Filter Ash Characterization Project } & tatus: On \\
\hline sponsors & \multicolumn{3}{|c|}{$\begin{array}{l}\text { Electric Power Research Institute (EPRD); Westinghouse; Lurgi Lentjes Babcock } \\
\text { (Germany); PowerGen; Schumacher Filters America; Electricité de France, } \\
\text { ECN/NOVEM (Netherlands); Electric Power Development Corporation (Japan); ABB- } \\
\text { Carbon (Sweden) }\end{array}$} \\
\hline \multicolumn{4}{|c|}{$\begin{array}{l}\text { Summary } \\
\text { The Electric Power Research Institute has organized a consortium to fund research to be performed at the Energy \& } \\
\text { Environmental Research Center to determine the coal- and system-related factors that lead to the formation of ash that } \\
\text { blinds and bridges hot-gas cleanup filters. The objectives are threefold: 1) to determine the mechanisms by which } \\
\text { difficult-to-clean ash is formed and how it blinds or bridges hot-gas filters; } 2 \text { ) to develop a method to determine the } \\
\text { rate of blinding or bridging based on analyses of the feed coal and sorbent and on the operating conditions; and } 3 \text { ) to } \\
\text { provide suggestions for preventing blinding and bridging. The work will encompass field sampling and laboratory-, } \\
\text { bench-, and pilot-scale testing. The main deliverable will be a computer model and database that could be used to } \\
\text { optimize energy system operating conditions, choose coals and sorbents, or design the cleanup system. } \\
\text { To date, over a dozen sets of samples, including coal, sorbent, bed material, and ashes, have been received from the } \\
\text { American Electric Power Tidd plant and are being analyzed by advanced scanning electron microscope and surface } \\
\text { science techniques. Samples have also been received and analyzed from the Grimethorpe pressurized fluidized-bed } \\
\text { combustor, the British Coal filter development rig, and the British Coal gas utilization facility filter. In addition, a } \\
\text { high-temperature powder tensile strength tester has been constructed, and thermochemical equilibrium modeling is } \\
\text { being performed with the University of Montreal FACT code. Five } 500 \text {-hour cake sintering tests have been } \\
\text { performed, and bench-scale testing simulating Tidd operating conditions has begun to determine factors affecting the } \\
\text { final size and composition distribution of filter ash particles. Also, pilot-scale sampling of entrained ashes and gas } \\
\text { entering the filter vessel of the EERC transport reactor development unit has been performed. }\end{array}$} \\
\hline & DOE Share, \$ & & \\
\hline & & & \\
\hline & & & \\
\hline
\end{tabular}




\begin{tabular}{|c|c|c|c|}
\hline Task 31 & \multicolumn{2}{|c|}{$\begin{array}{l}\text { Formal Evaluation of Flue Gas Chemical Measurement } \\
\text { Methods Phase I - Verification of Mercury Speciation by } \\
\text { EPA (Draft) Method } 29\end{array}$} & Status: Ongoing \\
\hline Cosponsor & \multicolumn{3}{|c|}{ Electric Power Research Institute } \\
\hline \multicolumn{4}{|c|}{$\begin{array}{l}\text { Summary } \\
\text { The original overall objective of the work was to determine whether EPA Method } 29 \text { can reliably quantify and } \\
\text { speciate mercury in the flue gas from coal-fired boilers. However, recent results indicated that it was necessary to } \\
\text { expand the project to include alternate mercury speciation methods. The methods currently being tested at the } \\
\text { Energy \& Environmental Research Center's pilot-scale combustor include the mercury speciation adsorption method } \\
\text { (MESA), the Ontario Hydro Method, and an acetate buffer method developed by Radian Corporation. } \\
\text { Test results have shown that when elemental mercury is spiked into the flue gas stream while a medium-sulfur } \\
\text { bituminous coal is being fired, }>60 \% \text { of the spiked elemental mercury is captured in the peroxide solutions of EPA } \\
\text { Method } 29 \text { using alternative methods for mercury sampling. It appears that the conversion of mercury occurs in the } \\
\text { flue gas; however, the results show that differences exist between methods. Bench-scale tests are currently under } \\
\text { way to determine the cause of these differences. }\end{array}$} \\
\hline Funding Profile & DOE Share, $\$$ & Nonfederal Share, \$ & \\
\hline FY94 & 287,090 & 447,852 & \\
\hline FYYS & & & \\
\hline
\end{tabular}


PROJECT DESCRIPTIONS AND STATUS

\begin{tabular}{|l|l|l|}
\hline Task 32 & $\begin{array}{l}\text { Organic Sulfur Removal from Coal with Super- and } \\
\text { Subcritical Water }\end{array}$ & Status: Ongoing \\
\hline Cosponsor & Illinois Clean Coal Institute \\
\hline
\end{tabular}

\section{Summary}

The main objective of this investigation is to develop an economically feasible method for the removal of organic sulfur and selected hazardous air pollutants (HAPs) from Illinois Basin high-sulfur coals for clean coal and nichemarket applications. Super- and subcritical water will be used as an extraction fluid rather than the traditional organic liquid solvents. This work will take advantage of supercritical (temperature $>374^{\circ} \mathrm{C}$, pressure $>218 \mathrm{~atm}$ ) and subcritical water for the removal of organic sulfur and selected HAPs by simply controlling the extraction temperature and pressure.

Extraction of Illinois bituminous coals under both super- and subcritical conditions was performed on raw IBC-101 bituminous coal to establish the baseline extraction conditions for organic sulfur removal. After the baseline conditions using raw IBC-101 were established, extractions were performed on raw and physically cleaned IBC-101 coal to evaluate the extraction conditions required for and the extent of organic sulfur removal. Preliminary data indicate that supercritical water extraction removed nearly three-fourths of the pyritic sulfur and one-half of the "organic" sulfur.

Extracted coal that would produce $<1.2 \mathrm{lb} \mathrm{SO}_{2} / \mathrm{MMBtu}$ (compliance fuel) was obtained from IBC-102 using the multigram unit. First attempts at catalytic desulfurization of the tar collected from the effluent water resulted in $0.6 \mathrm{wt} \%$ sulfur in tar from IBC-102 and $0.8 \mathrm{wt} \%$ sulfur in tar from IBC-101 with quantitative recovery of the tar. During the coming year, on-line desulfurization of tar is to be tested to make use of available hydrogen (nearly 2 mole \% of the gas) and heat and pressure from the extraction system.

In addition to organic sulfur removal, the second year of the current research program is expanded to include the investigation of selected HAPs (e.g., mercury) removal from coal with super- and subcritical water.

The scheduled completion date of the second-year investigation is August 31, 1996.

\begin{tabular}{|c|c|c|}
\hline Funding Profile & DOE Share, $\$$ & Nonfederal Share, $\$$ \\
\hline FY94 & 70,218 & 108,527 \\
\hline FY95 & 90,000 & 90,000 \\
\hline
\end{tabular}


PROJECT DESCRIPTIONS AND STATUS

\begin{tabular}{|c|c|c|c|}
\hline Task 33 & \multicolumn{2}{|c|}{$\begin{array}{l}\text { Upgraded North Dakota Lignite - Production of Test } \\
\text { Quantities }\end{array}$} & Status: Complete \\
\hline Cosponsor & \multicolumn{3}{|c|}{ North Dakota Industrial Commission } \\
\hline \multicolumn{4}{|c|}{$\begin{array}{l}\text { Summary } \\
\text { The objective of this project was to produce two 1-ton quantities of upgraded North Dakota lignite that would } \\
\text { subsequently be subjected to test burns (in a separate project) as a potential blend stock for pulverized coal } \\
\text { combustion. } \\
\text { Two selected North Dakota lignites were subjected to size reduction and classification and then treatment by wet } \\
\text { dense-media (magnetite) physical cleaning to reduce the inorganic (mineral) and pyrite contents. One cleaned lignite } \\
\text { was treated by the Energy \& Environmental Research Center hot-water-drying (HWD) technology. This technology } \\
\text { effectively reduced the moisture content of the coal, precluding reabsorption and, as well, diminished the alkali } \\
\text { content. The treated coals were aggregated via briquetting. Thermal treatment with superheated } \mathrm{N}_{2} \text { was used to } \\
\text { reduce the moisture content and increase the heating value of one briquetted lignite. The products met target } \\
\text { specifications for theoretical sulfur emissions, moisture level and heat content, sodium content, size, and ash content. } \\
\text { The final technical report was submitted in November } 1994 \text {. }\end{array}$} \\
\hline SUIU⿴囗十 & & & \\
\hline & $2 J, 000$ & & \\
\hline
\end{tabular}

\begin{tabular}{|l|l|l|}
\hline Task 34 & $\begin{array}{l}\text { Coal Quality Expert (CQE) Fouling and Slagging } \\
\text { Algorithm Development }\end{array}$ & Status: Ongoing \\
\hline Cosponsor & Black \& Veatch \\
\hline
\end{tabular}

Summary

Task 1 - Code Completion. This task will concentrate on completing/enhancing the previously developed codes so that no programming or concept errors remain. The work is nearly complete for both the fouling and the slagging code. Specific work to be completed includes development of slagging deposit removal mechanisms, integration of all algorithms into a time and temperature history algorithm, and output of all data into the CQE main program. This work includes completing all of the coding aspects as required by Black \& Veatch for complete integration into the CQE code. All of the programming guidelines that were outlined by Black \& Veatch in the past work will be continued.

Task 2 - Testing and Validation. This task will entail cooperation between the Energy \& Environmental Research Center and Black \& Veatch in "tuning" the fouling and slagging codes for optimum performance. Although these codes are state-of-the-art, they do contain a significant number of parameters for which experimental data are lacking. The codes will need to be designed to run under expected situations and conditions. Only a limited amount of validation will be performed with currently existing experimental results because of the lack of available quantitative data.

An alpha and beta version of both the fouling and slagging codes have been provided to Black \& Veatch. Validation of the codes are being performed with Black \& Veatch. The final versions of the codes will be delivered in the first quarter of 1996.

\begin{tabular}{|c|c|c|}
\hline Funding Profile & DOE Share, \$ & Nonfederal Share, $\$$ \\
\hline FY94 & 40,000 & 60,000 \\
\hline
\end{tabular}




\begin{tabular}{|c|c|c|c|}
\hline Task 35 & \multicolumn{2}{|c|}{$\begin{array}{l}\text { Evaluation of Field Analytical Techniques for Mercury in } \\
\text { Soil }\end{array}$} & Status: Ongoing \\
\hline Cosponsor & \multicolumn{3}{|c|}{$\begin{array}{l}\text { Gas Research Institute, NOVA Corporation of Alberta, General Electric, BioNebraska, } \\
\text { Spectrace }\end{array}$} \\
\hline \multirow{2}{*}{\multicolumn{4}{|c|}{$\begin{array}{l}\text { Summary } \\
\text { Within the natural gas industry there exists a need for fast, reliable analytical techniques for the quantitation of } \\
\text { mercury in soils. These techniques could potentially be used in initial investigations at mercury spill sites, as } \\
\text { guidance in site remediation activities, and for confirmation in postclosure monitoring. Within the last } 2 \text { years, } \\
\text { several techniques have been developed and refined that may be able to provide this capability. However, no } \\
\text { detailed comparison of these techniques to one another and to standard methods of analysis has been undertaken. } \\
\text { The objective of this project is to compare the accuracy and precision of four analytical techniques for the } \\
\text { quantitation of mercury in various soil types. Two of the techniques are commercially available, and the other two } \\
\text { are under development, including one being developed at Oak Ridge National Laboratory. }\end{array}$}} \\
\hline & & & \\
\hline \multicolumn{4}{|c|}{$\begin{array}{l}\text { Preliminary results indicate that several of the field-transportable analytical techniques have significant potential to } \\
\text { provide fast, reliable data for the quantitation of mercury in soil. One of the project cosponsors, NOVA } \\
\text { Corporation, has slightly modified one of the techniques and has been utilizing the modified technique for field } \\
\text { analysis with promising results. The final report has been delayed until first quarter } 1996 \text { so that the Nova } \\
\text { Corporation results can be incorporated. }\end{array}$} \\
\hline Funding Profile & DOE Share, $\$$ & Nonfederal Share, $\$$ & \\
\hline FY95 & 40,000 & 89,500 & \\
\hline
\end{tabular}

\begin{tabular}{|l|l|l|}
\hline Task 36 & $\begin{array}{l}\text { Combustion Characterization of Carbonized RDF from } \\
\text { Temperature Optimization Tests }\end{array}$ & Status: Ongoing \\
\hline Cosponsor & EnerTech Environmental Incorporated, City of Grand Forks \\
\hline
\end{tabular}

\section{Summary}

A refuse-derived fuel (RDF) obtained locally was converted through the Energy \& Environmental Research Center (EERC)-EnerTech carbonization process to a pumpable slurry fuel for use in a pilot-scale combustion test. The fuel was fired at a rate sufficient to maintain a furnace exit gas temperature of $2000^{\circ} \mathrm{F}$ at an excess air near $25 \%$. Results indicated excellent combustion efficiency, as more than $99.5 \%$ of the carbon was converted to $\mathrm{CO}_{2}$ and water. The fuel exhibited a very low ash fouling potential, and fly ash resistivity measurements indicated that adequate collection could be achieved using an electrostatic precipitator. The fly ash was also tested to determine the degree to which toxic trace elements would be leached from the fly ash in a disposal or reuse scenario. Analyses indicated that these toxic trace elements would not be leached from the fly ash above current standards.

The EERC is currently negotiating a development program that will include demonstration of an alternate method of dealing with municipal solid waste (MSW) involving presorting MSW followed by slurry carbonization to produce an energy-rich slurry fuel. This fuel will then be fired in EERC's test furnaces to demonstrate its technical and environmental viability. A preliminary engineering assessment of a full-scale facility to meet the future needs of the city of Grand Forks will also be included. The program is projected to start in January 1996.

\begin{tabular}{|c|c|c|}
\hline Funding Profile & DOE Share, $\$$ & Nonfederal Share, $\$$ \\
\hline FY95 & 200,000 & 304,096 \\
\hline
\end{tabular}




\begin{tabular}{|c|c|c|c|}
\hline Task 37 & \multicolumn{2}{|c|}{$\begin{array}{l}\text { Recent Advances in Research on Ash Deposition in } \\
\text { Utility Boilers: Practical Applications for the Electric } \\
\text { Power and Coal Industries }\end{array}$} & Status: Ongoing \\
\hline Cosponsor & \multicolumn{3}{|l|}{ Multiclients } \\
\hline \multicolumn{4}{|c|}{$\begin{array}{l}\text { Summary } \\
\text { Over the course of the past several years, significant advances have been made at the Energy \& Environmental } \\
\text { Research Center (EERC) in the understanding of ash behavior. These advances in understanding are leading to the } \\
\text { development of new methods to predict and mitigate ash-related problems. The advanced methods are much more } \\
\text { complex than those based on American Society for Testing and Materials (ASTM) analyses. The approach to the } \\
\text { problem involves a more quantitative understanding of the inorganic composition of the coal and the processes } \\
\text { involved in the formation of ash and ash deposits. The complexity of the problem creates a natural void between t } \\
\text { researcher and the practical engineer, operator, and designer. One of the most important issues is the need to } \\
\text { develop better communication among the researcher, coal company, boiler manufacturer, and utility. Common } \\
\text { ground between each of these members of the coal community must be established to facilitate the transfer of } \\
\text { information essential for solving ash-related problems. The objective of this program is to transfer technical } \\
\text { information concerning ash formation and ash deposition in utility boilers through the use of a short course. } \\
\text { To date, short courses have been presented in Orlando, Chicago, and Minneapolis. Additional short courses are } \\
\text { scheduled to be held in Petten (The Netherlands), Bismarck, Charleston, and Denver in } 1996 \text {. }\end{array}$} \\
\hline Funding Profile & DOE Share, \$ & Nonfederal Share, \$ & \\
\hline & 60,331 & & \\
\hline
\end{tabular}

\begin{tabular}{|l|l|l|}
\hline Task 38 & $\begin{array}{l}\text { Mercury Remediation Technology Research and } \\
\text { Demonstrations }\end{array}$ & Status: Ongoing \\
\hline Cosponsor & Gas Research Institute \\
\hline
\end{tabular}

\section{Summary}

This project involves research and demonstrations of commercial mercury remediation technologies for treating gas industry-contaminated soils. This work will be done at sites where commercial soil remediation activities are currently ongoing.

Two companies recently began offering mercury remediation technologies specifically designed to treat gas industry mercury-contaminated soils. The two companies are Earth Treatment Technologies (ETT), operating in Ohio, and Mercury Recovery Services (MRS), operating in New Mexico. ETT is using a combination of physical separation and chemical leaching (soil washing) to remove mercury from gas-industry soils that were shipped to this facility (a RCRA Part B treatment, storage, and disposal facility). MRS is using thermal retorting and has processed over 5000 tons of mercury-contaminated soil at their client's site. One ton of elemental mercury has been recovered for recycling. Both operations have been witnessed and sampled by EERC personnel. The final report is currently being written.

\begin{tabular}{|c|c|c|}
\hline Funding Profile & DOE Share, $\$$ & Nonfederal Share, $\$$ \\
\cline { 1 - 3 } FY95 & 40,000 & 60,500 \\
\hline
\end{tabular}




\begin{tabular}{|c|c|c|c|}
\hline Task 39 & \multicolumn{2}{|c|}{$\begin{array}{l}\text { Preparation and Gasification of Thailand Coal-Water } \\
\text { Fuels }\end{array}$} & Status: On \\
\hline Cosponsor & \multicolumn{3}{|c|}{ Department of Mineral Resources, Thailand } \\
\hline \multicolumn{4}{|c|}{$\begin{array}{l}\text { Summary } \\
\text { The project objective is to evaluate the technical feasibility of employing coal beneficiation techniques to upgrade } \\
\text { Thai lignite to generate a coal-water fuel. This fuel will then be gasified in an existing system at the Energy \& } \\
\text { Environmental Research Center. The gasification efficiency and heat energy content of the gas will be determined } \\
\text { from various measurements on the product gas and residual solids. } \\
\text { Approximately } 600 \mathrm{~kg} \text { of } 6 \text { in. } \times 0 \text { lignite was received in mid-October. The coal was sized and processed using } \\
\text { bench-scale cleaning and hydrothermal equipment. Cleaning resulted in a } 70 \% \text { reduction in ash, but only a moderate } \\
\text { reduction in sulfur content. Hydrothermal tests were conducted at three temperatures using raw coal ground to two } \\
\text { different particle-size distributions. Initial results indicate that a hydrothermally treated lignite can produce a } \\
\text { coal-water fuel with over } 50 \text { wt } \% \text { solids, which translates to a } 60 \% \text { improvement in energy density. The first } \\
\text { training session is with Thai personnel scheduled for mid-December during which time pilot-scale cleaning and } \\
\text { hydrothermal testing will be performed. Gasification tests are planned for February } 1996 \text {. }\end{array}$} \\
\hline $\mathrm{Fl}$ & & Nonfederal & \\
\hline & 49,771 & & \\
\hline
\end{tabular}

\begin{tabular}{|l|l|l|}
\hline Task 40 & Mercury Sorbent Evaluation & Status: Ongoing \\
\hline Cosponsor & Electric Power Research Institute (EPRI) & \\
\hline
\end{tabular}

\section{Summary}

The proposed project is a pilot-scale activity that will be conducted in an existing facility at the Energy \& Environmental Research Center (EERC). The purpose of the proposed project is to evaluate the mercury control ability of new sorbents that will be selected after discussions among U.S. Department of Energy, EPRI, and the EERC. Task 1 (the first year's work) has been modified. The focus of the program has switched from pilot- to bench-scale tests to evaluate sorbents for mercury control. EPRI has approved the purchase of an on-line mercury analyzer with Year 1 funds. The remainder of the funds will be used to develop a sorbent evaluation protocol using a fixed-bed bench-scale system. In Year 2, the work will continue with a focus on process conditions and their effect on the sorbents.

\begin{tabular}{|c|c|c|}
\hline Funding Profile & DOE Share, $\$$ & Nonfederal Share, $\$$ \\
\cline { 1 - 3 } FY95 & 60,350 & 89,650 \\
\hline
\end{tabular}




\begin{tabular}{|c|c|c|c|}
\hline Task 41 & \multicolumn{2}{|l|}{$\begin{array}{l}\text { Lignite Resource Chara } \\
\text { Mitigation of Ash Depo: }\end{array}$} & g \\
\hline 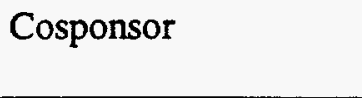 & \multicolumn{3}{|c|}{$\begin{array}{l}\text { Montana-Dakota Utilities; Knife River Coal Mining Company; North Dakota Industrial } \\
\text { Commission }\end{array}$} \\
\hline \multirow{2}{*}{\multicolumn{4}{|c|}{$\begin{array}{l}\text { Summary } \\
\text { The Energy \& Environm } \\
\text { optimize both mine coal } \\
\text { Beulah mine and the mir } \\
\text { Station has experienced } \\
\text { threatens the continued } \\
\text { examination of the coal } \\
\text { plant's operating charact } \\
\text { fouling and slagging. In } \\
\text { fouling and slagging in t } \\
\text { through this project have } \\
\text { result of stabilizing use } \\
\text { Coal samples have been } \\
\text { been completed. A shel } \\
\text { been developed. Two fi } \\
\text { verify the predictive cap }\end{array}$}} \\
\hline & & & \\
\hline & & & \\
\hline & & & \\
\hline
\end{tabular}

\begin{tabular}{|c|c|c|c|}
\hline Task 42 & \multicolumn{2}{|c|}{$\begin{array}{l}\text { Holocene Cyclicity in Western North Dakota-Climate } \\
\text { Change Interpreted from Fluctuations in Alluvial } \\
\text { Sedimentation }\end{array}$} & $\begin{array}{l}\text { Status: Negotiating with } \\
\text { commercial sponsor }\end{array}$ \\
\hline Cosponsor & \multicolumn{3}{|c|}{ Electric Power Research Institute } \\
\hline \multicolumn{4}{|c|}{$\begin{array}{l}\text { Summary } \\
\text { This project will interpret a portion of the postglacial climatic history of the northern plains by examining the alluvial } \\
\text { record in badlands terrain. Examination of this record for short-term cycles has not been previously attempted. } \\
\text { Knowing, however, the close connection between cycles of erosion and deposition and climate in semiarid landscapes } \\
\text { suggests this approach may prove very useful in interpreting paleoclimates and, hopefully, the cycles of change in the } \\
\text { recent past. Such interpretations would provide a new approach to examining climatic variability in the past, } \\
\text { reflecting periods of extended dry and moist conditions, and result in the development of a more rigorous context for } \\
\text { interpreting human interactions with both their physical and biotic surroundings. }\end{array}$} \\
\hline Funding Profile & DOE Share, \$ & Nonfederal Share, $\$$ & \\
\hline FY95 & 64,972 & 99,964 & \\
\hline
\end{tabular}




\begin{tabular}{|c|c|c|c|}
\hline Task 43 & \multicolumn{2}{|c|}{$\begin{array}{l}\text { Oxidation of North Dakota Scrubber Sludge for Soil } \\
\text { Amendment and Production of Gypsum }\end{array}$} & Status: Ongoing \\
\hline Cosponsor & \multicolumn{3}{|c|}{ Cooperative Power Associates, North Dakota Industrial Commission } \\
\hline \multicolumn{4}{|c|}{$\begin{array}{l}\text { Summary } \\
\text { The project for oxidation of North Dakota scrubber sludge will proceed in two phases. Phase I will focus on the } \\
\text { production of an agricultural soil amendment. The type of soil amendment to be produced is generally referred to as } \\
\text { agricultural gypsum; however, it is actually a mixture of calcium sulfate in several hydration states with a small } \\
\text { percentage of calcium hydroxide-carbonate. The actual gypsum content is less important than the oxidation of sulfite } \\
\text { in the original material to calcium sulfate. This material must be produced at a cost that allows it to compete in the } \\
\text { agriculture market. }\end{array}$} \\
\hline \multicolumn{4}{|c|}{$\begin{array}{l}\text { Phase II of this project will build on the processes developed and information gained in Phase I. Providing the } \\
\text { production of an agricultural soil amendment is economically viable, the actual gypsum production process will be } \\
\text { optimized for other markets such as wallboard production. The requirements for gypsum used in wallboard } \\
\text { production are much more stringent than for agricultural use; once again, the economic viability of the process will } \\
\text { be evaluated. }\end{array}$} \\
\hline \multicolumn{4}{|c|}{$\begin{array}{l}\text { Phase I of this project is under way and the sampling at Cooperative Power's Coal Creek Station has begun. Six } \\
\text { samples have been received and are being tested for key parameters and to evaluate consistency. Sampling protocol } \\
\text { is being established with the Coal Creek Station personnel based on the sample purity and consistency. }\end{array}$} \\
\hline Funding Profile & DOE Share, $\$$ & Nonfederal Share, 9 & \\
\hline FY95 & 40,000 & & \\
\hline
\end{tabular}

\begin{tabular}{|c|c|c|c|}
\hline Task 44 & \multicolumn{2}{|c|}{ Pilot Plant Assessment of Fly Ash Agglomeration } & Status: Ongoing \\
\hline Cosponsor & \multicolumn{3}{|c|}{ Thermal Energy Systems, Inc. (TESI) } \\
\hline \multicolumn{4}{|c|}{$\begin{array}{l}\text { Summary } \\
\text { The objective of this project is to evaluate the potential of the TESI in-furnace ionizer system and the Flaerex gas } \\
\text { conditioner/TESI ionization system to agglomerate fine particles and improve particulate collection efficiency by } \\
\text { electrostatic precipitation when applied to coal-fired boilers. A contract was executed with TESI during October of } \\
\text { this year and design of the ionization systems and associated flue gas sampling systems has begun. A project kickoff } \\
\text { meeting was held at the EERC on October } 16 \text { and } 17 \text { to discuss project goals and begin design of the ionizer systems }\end{array}$} \\
\hline \multicolumn{4}{|c|}{$\begin{array}{l}\text { To accommodate the in-furnace ionizer, a new burner design is required for the EERC's combustion test facility. } \\
\text { TESI is working toward completing the burner design, which will be constructed at the EERC. EERC activities to } \\
\text { this point have centered on redesign of the furnace exit and associated flue gas heat-transfer piping. Construction } \\
\text { activities are scheduled to begin in December. When the flue gas piping and ionization systems have been } \\
\text { constructed, system shakedown will begin. Four weeks of shakedown are planned, followed by four weeks of } \\
\text { testing, two weeks each for the in-furnace ionizer and the reverse-polarity ionizer preceding the electrostatic } \\
\text { precipitator. }\end{array}$} \\
\hline Funding Profile & DOE Share, \$ & Nonfederal Shar & \\
\hline FY95 & 209,993 & 318,007 & \\
\hline
\end{tabular}


PROJECT DESCRIPTIONS AND STATUS

\begin{tabular}{|c|c|c|c|}
\hline Task 45 & \multicolumn{2}{|c|}{$\begin{array}{l}\text { Small-Scale Demonstration of the Freeze-Thaw } \\
\text { Evaporation Process to Treat Oil and Gas Produced } \\
\text { Waters }\end{array}$} & Status: Ongoing \\
\hline Cosponsor & \multicolumn{3}{|c|}{ Gas Research Institute; AMOCO Production Company } \\
\hline \multicolumn{4}{|c|}{$\begin{array}{l}\text { Summary } \\
\text { The freeze-thaw evaporation (FTE) demonstration project is being conducted to evaluate the economical coupling of } \\
\text { the freeze crystallization water purification process with evaporation in order to reduce the volumes of oil- and } \\
\text { gas-related produced waters that ultimately require disposal in Class II injection wells, as well as to evaluate the } \\
\text { freeze crystallization process to produce a reusable quality of purified water. Project activities completed to date } \\
\text { (November 1995) have included the acquisition of regulatory approval from the State of New Mexico's Oil } \\
\text { Conservation Division and the construction and installation of equipment at the technology demonstration facility. } \\
\text { Hydrostatic testing of the piping, pumps, tanks, and related instrumentation has also been conducted. } \\
\text { Operation of the freezing process is scheduled to begin in late November } 1995 \text { and will continue as long as freezing } \\
\text { conditions (sub } 32^{\circ} \mathrm{F} \text { temperatures) exist at the demonstration facility. This will be followed by the observation of } \\
\text { the evaporation process during the spring and summer months of } 1996 \text {, followed by evaluation of data for the } \\
\text { coupled FTE process and final report preparation. }\end{array}$} \\
\hline Funding Profile & DOE Share, \$ & Nomederal snare & \\
\hline FY95 & 200,000 & 600,000 & \\
\hline
\end{tabular}


SECTION B

\title{
PROJECTS PROPOSED
}

\author{
FOR FY96 FUNDING
}


TABLE B-1

CURRENTLY FUNDED JSRP PROJECTS THAT WILL RECEIVE ADDITIONAL JSRP FUNDING IN FY96

\begin{tabular}{|c|c|c|c|}
\hline Task No. & Title & $\begin{array}{l}\text { Planned FY96 } \\
\text { DOE Funding, \$ }\end{array}$ & $\begin{array}{l}\text { Planned FY96 } \\
\text { Commercial } \\
\text { Funding, } \$\end{array}$ \\
\hline 17 & $\begin{array}{l}\text { Enhanced Air Toxics Control } \\
\text { Cosponsor - Electric Power Research Institute (EPRI) }\end{array}$ & 120,000 & 180,000 \\
\hline 18 & $\begin{array}{l}\text { Coal Ash Resources Research Consortium (CARRC) 1994-1995 } \\
\text { Research } \\
\text { Cosponsors - Otter Tail Power Company, Cooperative Power, Contech, } \\
\text { J.W. Brett, Inc., Northern States Power Company, Nebraska Ash, and } \\
\text { TransAlta Utilities Corporation }\end{array}$ & 85,000 & 125,000 \\
\hline 20 & $\begin{array}{l}\text { FT-IR Spectroscopy Investigation of Fireside Deposits in a Pilot Plant } \\
\text { Combustor } \\
\text { Cosponsor - Electric Power Research Institute }\end{array}$ & 60,000 & 90,000 \\
\hline 23 & $\begin{array}{l}\text { Gas Industry Groundwater Research Program } \\
\text { Cosponsor - Gas Research Institute }\end{array}$ & 400,000 & 400,000 \\
\hline 28 & $\begin{array}{l}\text { An Assessment of the Subsurface Fate of Monoethanolamine at Sour } \\
\text { Gas Processing Plant Sites } \\
\text { Cosponsors - Canadian Association of Petroleum Producers and } \\
\text { Canadian Occidental Petroleum Ltd. }\end{array}$ & 50,000 & 75,000 \\
\hline 30 & $\begin{array}{l}\text { Hot Gas Filter Ash Characterization Project } \\
\text { Cosponsor - Electric Power Research Institute }\end{array}$ & 275,000 & 335,000 \\
\hline 31 & $\begin{array}{l}\text { Formal Evaluation of Flue Gas Chemical Measurement Methods } \\
\text { Phase I - Verification of Mercury Speciation by EPA (Draft) Method } 29 \\
\text { Cosponsor - Electric Power Research Institute }\end{array}$ & 300,000 & 450,000 \\
\hline 40 & $\begin{array}{l}\text { Mercury Sorbent Evaluation } \\
\text { Cosponsor - Electric Power Research Institute }\end{array}$ & 64,000 & 96,000 \\
\hline \multicolumn{2}{|l|}{ TOTAL } & $1,354,000$ & $1,751,000$ \\
\hline
\end{tabular}


PROPOSED NEW JSRP PROJECTS

\begin{tabular}{|c|c|c|c|c|c|}
\hline \multirow[b]{2}{*}{ Project No. } & \multirow[b]{2}{*}{ Title } & \multirow{2}{*}{$\begin{array}{l}\text { FY96 DOE } \\
\text { Funding, } \$\end{array}$} & \multirow{2}{*}{$\begin{array}{l}\text { Nonfederal } \\
\text { Funding, } \$ \\
\end{array}$} & \multicolumn{2}{|c|}{ Future DOE Funding, $\$$} \\
\hline & & & & FY97 & FY98 \\
\hline \multicolumn{6}{|c|}{ Projects for Which Proposals Have Been Submitted to DOE } \\
\hline $96-1$ & $\begin{array}{l}\text { Training and Support for Hot-Gas Filter Testing } \\
\text { Cosponsors - 3M, Industrial Filter \& Pump, and Paul Advanced Filters }\end{array}$ & 20,539 & 20,539 & 0 & 0 \\
\hline $96-2$ & $\begin{array}{l}\text { Development of a Coal Combustion Byproducts (CCBs) } \\
\text { Database System } \\
\text { Cosponsor - American Coal Ash Association }\end{array}$ & 19,800 & 29,700 & 0 & 0 \\
\hline \multicolumn{6}{|c|}{ Projects for Which Proposals Have Been Submitted to Commercial Sponsors } \\
\hline $96-3$ & $\begin{array}{l}\text { Coal Ash Behavior in Reducing Environments (CABRE) II } \\
\text { Cosponsors - Destec, Texaco, Demkolec, Krupp-Koppers, Electric Power } \\
\text { Research Instinute and NOVEM }\end{array}$ & 118,000 & 242,000 & 118,000 & 118,000 \\
\hline $96-4$ & $\begin{array}{l}\text { Utilization of Petroleum Coke for Power Production } \\
\text { Cosponsors - Mobil and Electric Power Research Insiture }\end{array}$ & 44,000 & 66,000 & 44,000 & 44,000 \\
\hline \multicolumn{6}{|c|}{ Projects for Which the EERC is Ready to Write Proposals with Commercial Sponsors } \\
\hline $96-5$ & $\begin{array}{l}\text { Development of Hydrothermal Treatment for Wastewater } \\
\text { and Economic Development } \\
\text { Cosponsor - EESI (a small business concern in New Mexico) }\end{array}$ & 40,000 & 60,000 & 0 & 0 \\
\hline $96-6$ & $\begin{array}{l}\text { Removal of Hazardous Heavy Metals from Wastewater } \\
\text { with Activated Carbons } \\
\text { Cosponsors - Lewis Environmental Services, Inc. and 3M }\end{array}$ & 60,000 & 90,000 & 0 & 0 \\
\hline \multicolumn{6}{|c|}{ Projects under Discussion with Commercial Sponsors } \\
\hline $96-7$ & $\begin{array}{l}\text { Investigation of the Effects of Low-NO } \mathrm{Nu}_{\mathrm{x}} \text { Burner } \\
\text { Technologies on Coal Combustion Byproducts and } \\
\text { Resulting Utilization Characteristics } \\
\text { Cosponsors - Tennessee Valley Authority, Cinergy, Northern Indiana } \\
\text { Public Service Company, Edison Electric Institute, and American Electric } \\
\text { Power }\end{array}$ & 80,000 & 120,000 & 80,000 & 80,000 \\
\hline 96-8 & $\begin{array}{l}\text { Mercury Sorbent Consortium } \\
\text { Cosponsors - Dravo Lime, Calgon. Alcoa, American Norit, and other } \\
\text { carbon/sorbent manufacturers }\end{array}$ & 100,000 & 150,000 & 0 & 0 \\
\hline $96-9$ & $\begin{array}{l}\text { Optimizing Coal Utilization, Cleaning, and Blending at the } \\
\text { Mine Level } \\
\text { Cosponsors - Coal companies, utilities, and Electric Power Research } \\
\text { Instinute (consortium) }\end{array}$ & 150,000 & 225,000 & 150,000 & 150,000 \\
\hline $96-10$ & $\begin{array}{l}\text { Fuel Quality Advisor } \\
\text { Cosponsors - Coal companies, utilities, and Electric Power Research } \\
\text { Institute (consortium) }\end{array}$ & 200,000 & 300,000 & 200,000 & 200,000 \\
\hline $96-11$ & $\begin{array}{l}\text { Advanced Analytical Information System } \\
\text { Cosponsors - Utilities, coal companies, and Electric Power Research } \\
\text { Instirure }\end{array}$ & 180,000 & 270,000 & 180,000 & 0 \\
\hline
\end{tabular}




\begin{tabular}{|c|c|c|c|c|c|}
\hline \multirow[b]{2}{*}{ Project No. } & \multirow[b]{2}{*}{ Title } & \multirow{2}{*}{$\begin{array}{c}\text { FY96 DOE } \\
\text { Funding, } \$\end{array}$} & \multirow{2}{*}{$\begin{array}{l}\text { Nonfederal } \\
\text { Funding, \$ }\end{array}$} & \multicolumn{2}{|c|}{ Future DOE Funding, \$ } \\
\hline & & & & FY97 & FY98 \\
\hline $96-12$ & $\begin{array}{l}\text { Field Demonstration of SPME-IR Spectroscopy Field } \\
\text { Screening of Soil Contaminated by Hazardous Waste and } \\
\text { Toxic Chemical Spills } \\
\text { Cosponsors - Gas Research Instinte, American Petroleum Instiute, } \\
\text { Petroleum Environmental Research Forum, Amoco, and Bomem }\end{array}$ & 40,000 & 60,000 & 100,000 & 0 \\
\hline $96-13$ & $\begin{array}{l}\text { Circulating Fluidized-Bed Combustion (CFBC) of Low- } \\
\text { Grade Fuels } \\
\text { Cosponsors - Boiler vendors, biomass groups, and industrial boiler } \\
\text { operators }\end{array}$ & 80,000 & 120,000 & 120,000 & 120,000 \\
\hline $96-14$ & $\begin{array}{l}\text { Evaluation of Natural Clay Liners for Produced Water } \\
\text { Impoundments } \\
\text { Cosponsors - Gas Research Instiute, American Petroleum Instinute, } \\
\text { Petroleum Environmental Research Forum, and Amoco }\end{array}$ & 100,000 & 300,000 & 20,000 & 0 \\
\hline $96-15$ & $\begin{array}{l}\text { Adsorbed Natural Gas (ANG) Vehicle Fueling } \\
\text { Cosponsors - Gas Research Instinte, Northern States Power Company, } \\
\text { Amoco, Bninswick Composites, New Flyer of America, and various } \\
\text { activated carbon producers }\end{array}$ & 53,000 & 80,000 & 0 & 0 \\
\hline $96-16$ & $\begin{array}{l}\text { Fouling and Slagging Assessment of an Upgraded North } \\
\text { Dakota Lignite } \\
\text { Cosponsors - North Dakota Industrial Commission, University of } \\
\text { Southern Illinois, and Sargent \& Lundy }\end{array}$ & 46,970 & 70,455 & 0 & 0 \\
\hline $96-17$ & $\begin{array}{l}\text { Development of a Catalyst-Coated Fabric Filter for } \\
\text { Simultaneous } \mathrm{No}_{x} \text { and Particulate Control } \\
\text { Cosponsor - Owens-Corning }\end{array}$ & 100,000 & 150,000 & 50,000 & 50,000 \\
\hline $96-18$ & $\begin{array}{l}\text { Utilization of Paper Mill Sludge in Pulverized Coal-Fired } \\
\text { Boilers } \\
\text { Cosponsor - Rainy River Corporation }\end{array}$ & 32,000 & 48,000 & 0 & 0 \\
\hline \multicolumn{6}{|c|}{ Projects for Which the EERC is Developing the Idea Internally } \\
\hline $96-19$ & $\begin{array}{l}\text { Refining the Application of FT-IR Spectroscopy for } \\
\text { Monitoring Combustor Deposits } \\
\text { Cosponsors - Electric Power Research Institute and Clean Air } \\
\text { Engineering }\end{array}$ & 34,000 & 50,000 & 34,000 & 0 \\
\hline $96-20$ & $\begin{array}{l}\text { Evaluating the Efficiency of Selected Sorbents for } \\
\text { Removing Mercury from Natural Gas Reservoirs } \\
\text { Cosponsors - Central Environmental Inc., Gas Research Institute, and } \\
\text { other oil and gas companies }\end{array}$ & 140,000 & 210,000 & 140,000 & 0 \\
\hline $96-21$ & $\begin{array}{l}\text { Development of an Infrared-Based Instrument for } \\
\text { Measuring Combustion Deposit Thickness } \\
\text { Cosponsors - Electric Power Research Instiute, Diamond Power, and } \\
\text { other electrical utilities }\end{array}$ & 80,000 & 120,000 & 0 & 0 \\
\hline $96-22$ & $\begin{array}{l}\text { Effect of Dust Properties on Particulate Control } \\
\text { Cosponsors - BHA Group Inc., W.L. Gore, particulate control vendors, } \\
\text { and other fabric vendors }\end{array}$ & 80,000 & 120,000 & 80,000 & 0 \\
\hline
\end{tabular}


TABLE B-2 (continued)

\begin{tabular}{|c|c|c|c|c|c|}
\hline \multirow[b]{2}{*}{ Project No. } & \multirow[b]{2}{*}{ Title } & \multirow{2}{*}{$\begin{array}{l}\text { FY96 DOE } \\
\text { Funding, \$ }\end{array}$} & \multirow{2}{*}{$\begin{array}{l}\text { Nonfederal } \\
\text { Funding, } \$ \\
\end{array}$} & \multicolumn{2}{|c|}{ Future DOE Funding, \$ } \\
\hline & & & & FY97 & FY98 \\
\hline $96-23$ & $\begin{array}{l}\text { Upgrading Coal Fines with Nonrecyclable Wastes } \\
\text { Cosponsors - Coal companies, American Plastics Council (APC), Electric } \\
\text { Power Research Institute, North Dakota Industrial Commission, waste } \\
\text { companies, and industrial boiler owners }\end{array}$ & 40,000 & 60,000 & 80,000 & 0 \\
\hline $96-24$ & $\begin{array}{l}\text { Minimizing Opacity Using In-Furnace Ash Agglomeration } \\
\text { Cosponsors - Minnesota Power, Thermal Energy Systems, Inc., and } \\
\text { Westmoreland Resources }\end{array}$ & 20,000 & 30,000 & 100,000 & 100,000 \\
\hline \multicolumn{6}{|c|}{ Projects for Which the Basic Idea Exists } \\
\hline $96-25$ & $\begin{array}{l}\text { Catalytic Hydrothermal Treatment for Fuel Cell } \\
\text { Applications } \\
\text { Cosponsors - Fuel cell vendors, coal companies, biomass groups, and } \\
\text { municipalities }\end{array}$ & 40,000 & 60,000 & 100,000 & 0 \\
\hline TOTAL & & $1,898,309$ & $3,051,694$ & $1,596,000$ & 862,000 \\
\hline
\end{tabular}

\begin{tabular}{|l|c|c|}
\hline Totals & Federal Funding, \$ & Commercial Funding, \$ \\
\hline $\begin{array}{l}\text { Currently Funded Projects That Will Receive Additional Funding in } \\
\text { FY96 }\end{array}$ & $1,354,000$ & $1,751,000$ \\
\hline Proposed New Projects & $1,898,309$ & $3,051,694$ \\
\hline Grand Total & $\mathbf{3 , 2 5 2 , 3 0 9}$ & $\mathbf{4 , 8 0 2 , 6 9 4}$ \\
\hline
\end{tabular}




\begin{tabular}{|c|c|c|}
\hline \multirow{2}{*}{\multicolumn{2}{|c|}{$\begin{array}{l}\text { PROAECT TITLE } \\
\text { Training and Support for Hot-Gas Filter Testing }\end{array}$}} & \multirow{2}{*}{$\begin{array}{l}\text { 1995 JV LIST NUMBER } \\
\text { NA } \\
\text { CA TASK NUMBER } \\
\text { NA } \\
\end{array}$} \\
\hline & & \\
\hline $\begin{array}{l}\text { SUGGESTED PERFORMANCE MONITOR } \\
\text { Richard Dennis }\end{array}$ & $\begin{array}{l}\text { EERC PROJECT MANAGER } \\
\text { Michael Mann }\end{array}$ & $\begin{array}{l}\text { CONTROL NUMBER } \\
96-1\end{array}$ \\
\hline $\begin{array}{l}\text { PROJECT PERIOD } \\
\text { Start: } 11-1-95\end{array}$ & End: 3-31-96 & $\begin{array}{l}\text { SUBMISSION DATE } \\
10-30-95\end{array}$ \\
\hline
\end{tabular}

PARTICIPANTS

3M, Industrial Filter \& Pump, and Paul Advanced Filters

WORK DESCRIPTION (SUMMARY)

The University of North Dakota Energy \& Environmental Research Center is proposing a program entitled "Training and Support for Hot-Gas Filter Testing" as part of the Jointly Sponsored Research Program. The overall goal of this program is to maximize the exchange of information during the upcoming 200-hour filter test on the transport reactor development unit. Specifically, the Energy \& Environmental Research Center would assist vendors witnessing the test in obtaining photos, samples, and hard data documenting the test; expand reporting and report distribution; provide training activities on start-up, operation, and troubleshooting; and allow for testing of four different filter types, rather than three.

\begin{tabular}{|l|l|l|l|l|}
\hline YEAR & FY96 & & & \\
\hline TOTAL FUNDING: & 41,078 & & & \\
\hline NONFEDERAL FUNDING & & & & \\
\hline Contract Award--Cash & & & & \\
\hline In-Kind Contribution & 20,539 & & & \\
\hline DOE FUNDING: & 20,539 & & & \\
\hline FUNDS REQUESTED THIS ACTION: & 20,539 & & & \\
\hline
\end{tabular}




\begin{tabular}{|c|c|c|}
\hline \multicolumn{2}{|c|}{$\begin{array}{l}\text { PROAECT TITLE } \\
\text { Development of a Coal Combustion Byproducts (CCBs) Database System }\end{array}$} & \\
\hline \multirow{2}{*}{\multicolumn{2}{|c|}{\begin{tabular}{l|l} 
SUGGESTED PERFORMANCE MONITOR & $\begin{array}{l}\text { EERC PRONECT MANAGER } \\
\text { Erin O'Leary }\end{array}$ \\
PROJECT PERIOD & \\
Start: $10-1-95$ & End: $9-30-97$
\end{tabular}}} & $\begin{array}{l}\text { NA } \\
\text { NA TASK NUMBER } \\
\text { CONTROL NUMBER }\end{array}$ \\
\hline & & $\begin{array}{l}\text { SUBMGSSION DATE } \\
11-8-95\end{array}$ \\
\hline
\end{tabular}

WORK DESCRIPTION (SUMMARY)

Develop a computer database and application program to contain analytical and engineering information on coal combustion byproducts. Data will be collected from American Coal Ash Association members and input to the database. A complete database application, manual, and final report will be delivered to American Coal Ash Association and U.S. Department of Energy .

\begin{tabular}{|l|c|l|l|l|}
\hline YEAR & FY96 & & & \\
\hline TOTAL FUNDING: & 49,500 & & & \\
\hline NONFEDERAL FUNDING & & & & \\
\hline Contract Award-Cash & 29,700 & & & \\
\hline In-Kind Contribution & & & & \\
\hline DOE FUNDING: & 19,800 & & & \\
\hline FUNDS REQUESTED THIS ACTION: & 19,800 & & & \\
\hline
\end{tabular}


Project Title

Coal Ash Behavior in Reducing Environments (CABRE) II

Potential Partner(s)

Destec, Texaco, Demkolec, Krupp-Koppers, Electric Power Research Institute, and NOVEM

Project Objectives

- To advance the current fundamental understanding of ash formation and deposition in entrained-flow gasification systems by correlating them with an applied engineering understanding

- To propose and test methods of deposit mitigation for the different types of deposition present in entrained-flow gasification systems

- To develop a series of indices for predicting the potential for deposition in an entrained-flow gasification system as a function of coal properties, system configuration, and operating parameters

Target Start Date

February 1996

Contact Person(s)

Tom Erickson or David Brekke

Project Maturity (Check one)

$\square$ Proposal submitted to commercial sponsor(s)

Ready to write proposal to commercial sponsor(s)

Discussing with potential sponsor(s)

Developing idea internally

Basic idea exists

Applicability to Fossil Energy Objectives

The successful design and operation of coal gasification and advanced combustion systems depends on the ability to control and mitigate ash-related problems. The economic and environmental implications of slag flow control, slag attack on refractory, ash deposition on heat-transfer surfaces, corrosion and erosion of system materials, and emissions control are well documented. Minimizing the potential for these ash-related problems is a fundamental objective in designing and operating entrained-flow gasifiers and advanced combustion systems. The CABRE II project will provide evaluation tools for design engineers and operators of these systems to aid in the assessment of fuel requirements and operating conditions.

Project Description

The CABRE II program is a 3-year multiclient program set in four tasks. The overall purpose of Task 1 is to advance the current fundamental understanding of ash formation by correlating ash characteristics in large-scale systems with their operational parameters. Ash formation and decomposition will be assessed on the effects of an $\mathrm{H}_{2} \mathrm{~S}$ atmosphere, short residence time transformations, and the formation of submicron or aerosol particles, largely through the use of a pressurized entrained-flow gasification simulator. Task 2 will focus on the incorporation of engineering and systems applications designed to best mimic the deposition attributes of large-scale systems. This will involve field discussions and sample collection at largescale sites, laboratory testing of strength and growth rates in bench-scale units, and viscosity modeling of ash and deposits. Task 3 will use the information gained from CABRE I and CABRE II to develop a series of deposition indices that will aid designers and operators in the mitigation of ash-related problems. Demonstrations of the models on sponsor systems will be performed. Task 4 is the management and reporting functions of the program.

\begin{tabular}{|l|c|c|c|}
\hline & FY96 & FY97 & FY98 \\
\hline Federal Funds, \$ & 118,000 & 118,000 & 118,000 \\
\hline Nonfederal Funds, \$ & 242,000 & 242,000 & 242,000 \\
\hline Total Funds, \$ & 360,000 & 360,000 & 360,000 \\
\hline
\end{tabular}


Project Title

Utilization of Petroleum Coke for Power Production

Potential Partner(s)

Mobil and EPRI

Project Objective

The objective for the proposed project is to determine the impacts of using petroleum coke as a primary or blended fuel for conventional coal-fired power systems on system performance, efficiency, and emissions.

\begin{tabular}{|c|c|}
\hline \multicolumn{2}{|c|}{$\begin{array}{l}\text { Target Start Date } \\
\text { December } 1995\end{array}$} \\
\hline \multicolumn{2}{|c|}{$\begin{array}{l}\text { Contact Person } \\
\text { Chris Zygarlicke }\end{array}$} \\
\hline \multicolumn{2}{|c|}{ Project Maturity (Check one) } \\
\hline$\nabla$ & $\begin{array}{l}\text { Proposal submitted to commercial } \\
\text { sponsor(s) }\end{array}$ \\
\hline$\square$ & $\begin{array}{l}\text { Ready to write proposal to } \\
\text { commercial sponsor(s) }\end{array}$ \\
\hline$\square$ & Discussing with potential sponsor(s) \\
\hline$\square$ & Developing idea internally \\
\hline & Basic idea exists \\
\hline
\end{tabular}

Applicability to Fossil Energy Objectives

This project satisfies the Fossil Energy goals and objectives in relation to broadening fossil fuel end-use applications and reducing the environmental impact of waste products from fossil fuel combustion. Improved strategies for the clean and efficient use of petroleum coke as a fuel will result from this project. Information on slagging, fouling, and air toxic emissions and on fly ash utilization as related to petroleum coke combustion will lead to environmental and economic gains for the energy industry.

Project Description

The purpose of this project is to provide a sound technological characterization of the system and environmental impacts in utilizing petroleum coke or coke-coal blends for conventional coal combustion applications. Several cokes would be selected, and standard analyses and innovative methods would be employed to determine the inorganic content of coke and the association of the minerals and organically bound organics. Combustion tests would then be performed on the cokes using bench- and pilotscale furnaces. Laminar flow drop-tube furnaces would be used to screen coke-coal blends for optimum blend ratios that minimize fouling, slagging, and $\mathrm{SO}_{2}$ emissions. Optimal coke-coal blends would then be fired in the Energy \& Environmental Research Center Combustion Test Facility (CTF) reactor to evaluate the performance of the fuel in a more realistic system. The Combustion Test Facility system would also produce enough fly ash to perform ash utilization assessments. Overall issues of handling and feeding petroleum coke into a full-scale boiler would also be addressed. Final verification of optimum coke-coal blend ratios and firing modes would be performed in collaboration with a host utility.

\begin{tabular}{|l|c|c|c|}
\hline & FY96 & FY97 & FY98 \\
\hline Federal Funds, \$ & 44,000 & 44,000 & 44,000 \\
\hline Nonfederal Funds, \$ & 66,000 & 66,000 & 66,000 \\
\hline Total Funds, \$ & 110,000 & 110,000 & 110,000 \\
\hline
\end{tabular}


Project Title

Development of Hydrothermal Treatment for Wastewater and Economic Development

Potential Partner(s)

EESI (a small business concern in New Mexico)

Project Objective

To provide a quick, simple means of cleaning contaminated water for immediate return to the environment.

\begin{tabular}{|l|}
$\begin{array}{l}\text { Target Start Date } \\
\text { July } 1,1996\end{array}$ \\
\hline $\begin{array}{l}\text { Contact Person } \\
\text { Peter Louie }\end{array}$ \\
\hline Project Maturity (Check one) \\
$\square$ Proposal submitted to commercial \\
sponsor(s) \\
$\square$ Ready to write proposal to \\
commercial sponsor(s) \\
$\square$ Discussing with potential sponsor(s) \\
$\square$ Developing idea internally \\
$\square$ Basic idea exists
\end{tabular}

Applicability to Fossil Energy Objectives

Over the past $100+$ years, the use of fossil fuel liquids (petroleum products and coal oil) has been the most popular form of energy production. Along with the combustion of the fuels came the necessity of handling larger and larger quantities of their liquids. In the handling process, fuel spillages, container leakages and tank overflows have been common, resulting in contaminated soils. In addition, electrical transformer Polychlorinated Biphenyls spills, transmission oil leaks, and heavy grease losses from lubricated mechanical parts resulted in deposits in soils. Pesticide deposits and industrial and household waste deposits in soil are common. Water leaches these contaminates along with hazardous metals; these must be removed from the water prior to its release back to the environment. Development of the proposed technology will provide a quick and relatively easy means to clean up this wastewater, providing a cleaner environment and encouraging economic development.

\section{Project Description}

The versatility of hydrothermal treatment as an organic destruction method is gaining recognition. In general, hydrothermal treatment refers to the redox reactions of chemical compounds in aqueous streams under supercritical or near-critical conditions. One important application of hydrothermal treatment is the destruction of organics in aqueous wastes. The reaction is carried out entirely in an enclosed pressure vessel and in dilute concentration, so that the heat of the reaction is adsorbed by the solvent, and the temperature can be maintained at any desirable level, typically in the range of $300^{\circ}-550^{\circ} \mathrm{C}$.

The objective of the proposed research and development project is to demonstrate an innovative hydrothermal boiler system that can accomplish the following:

- Treat hazardous wastes from coal gasification plants and fuel, pesticide, and industrial organic spillages

- Remove inorganics and organics for the protection of energy recovery equipment and production of clean water

- Develop a skid-mounted hydrothermal boiler system that can be demonstrated at customer sites

- Be readily licensable under Resource Conservation Recovery Act Boiler and Industrial Furnace Rules

The Energy \& Environmental Research Center is interested in playing an active role in developing the proposed waste treatment process with EESI (a small business concern in New Mexico). In particular, the Energy \& Environmental Research Center is interested in the Phase I bench-scale organic reforming to vapor for energy recovery and organic separation from inorganics for heterogeneous wastes portion of the work scope.

\begin{tabular}{|l|c|c|c|}
\hline & FY96 & FY97 & FY98 \\
\hline Federal Funds, \$ & 40,000 & 0 & 0 \\
\hline Nonfederal Funds, \$ & 60,000 & 0 & 0 \\
\hline Total Funds, \$ & 100,000 & 0 & 0 \\
\hline
\end{tabular}


Project Title

Removal of Hazardous Heavy Metals from Wastewater with Activated Carbons

Potential Partner(s)

Lewis Environmental Services, Inc. and 3M

Project Objective

The selective segmental adsorption by activated carbon derived from coal and other sorbent materials will be used to remove hazardous heavy metals from contaminated wastewater to levels that meet existing EPA discharge limits and regulations.

\begin{tabular}{|l|}
\hline Target Start Date \\
July 1,1996 \\
\hline Contact Person \\
Peter Louie \\
\hline Project Maturity (Check one) \\
$\square \quad$ Proposal submitted to commercial \\
sponsor(s) \\
$\square \quad$ Ready to write proposal to \\
commercial sponsor(s) \\
$\square$ Discussing with potential sponsor(s) \\
$\square$ Developing idea internally \\
$\square$ Basic idea exists \\
\hline
\end{tabular}

Applicability to Fossil Energy Objectives

The coal-derived activated carbon represents new applications of coal for wastewater treatment applications.

Project Description

The system proposed involves a series of four modules in which each has a specific purpose in the remediation process. In Module 1, we will use activated carbon to remove the organic compounds most commonly found in aqueous mixed waste streams. We will then, in Modules 2 and 3, use chemically treated activated carbon to remove moderate-to-high concentrations of hazardous heavy metals (e.g., eight Resource Conservation Recovery Act elements). Module 4, the final polishing step, will use selective carbon-based sorbent materials to handle low-concentration heavy metals-contaminated waste streams. An electrolytic recovery process developed by Lewis Environmental Services, Inc., will then recycle the heavy metals into a recyclable and saleable end product. Thus minimum waste generation will be achieved.

The project will involve further refinement of the Lewis Environmental Services, Inc. process, and develop a predictive model for the heavy metals removal process. We propose to conduct our investigation through a series of bench-scale tests using bench-scale module provided by Lewis Environmental Services, Inc. within a 12-month program schedule at the Energy \& Environmental Research Center. Bench scale $(1-\mathrm{gal} / \mathrm{min})$ investigation will involve treatment of coal-derived aqueous waste streams.

\begin{tabular}{|l|c|c|c|}
\hline & FY96 & FY97 & FY98 \\
\hline Federal Funds, \$ & 60,000 & 0 & 0 \\
\hline Nonfederal Funds, \$ & 90,000 & 0 & 0 \\
\hline Total Funds, \$ & 150,000 & 0 & 0 \\
\hline
\end{tabular}


Project Title

Investigation of the Effects of Low-NO $\mathrm{x}$ Burner Technologies on Coal Combustion Byproducts and Resulting Utilization Characteristics

Potential Partner(s)

Tennessee Valley Authority, Cinergy, Northern Indiana Public Service Company, Edison Electric Institute, and American Electric Power

Project Objective

To determine mechanisms of inorganic transformations under low- $\mathrm{NO}_{x}$ combustion conditions, determine the impact of low $-\mathrm{NO}_{x}$ combustion on coal combustion byproducts, and develop byproduct management strategies.

Target Start Date
April 1, 1996

Contact Person

Debra Pflughoeft-Hassett

Project Maturity (Check one)

Proposal submitted to commercial sponsor(s)

$\square$ Ready to write proposal to commercial sponsor(s)

$\square$ Discussing with potential sponsor(s)

Developing idea internally

Basic idea exists

Applicability to Fossil Energy Objectives

Fulfills U.S. Department of Energy objectives in the area of disposition or use of solid wastes. The project will provide information and recommendations that will facilitate the utilization of coal combustion by-products produced under full-scale low- $\mathrm{NO}_{\mathrm{x}}$ combustion conditions.

Project Description

Utility coal combustion fly ash and bottom ash samples from a variety of sources utilizing low-NO $\mathrm{N}_{\mathrm{x}}$ burners will be collected and evaluated for select properties related to utilization and disposal requirements. Bench-scale combustion tests will be performed to evaluate operational parameters relative to improving ash quality for potential utilization and determining the trace element transformations in low-NO $\mathrm{N}_{\mathrm{x}}$ combustion. Carbon separation techniques will be applied to samples as a potential beneficiation procedure. Specific recommendations for operational parameters and carbon separation will be made.

\begin{tabular}{|l|c|c|c|}
\hline & FY96 & FY97 & FY98 \\
\hline Federal Funds, \$ & 80,000 & 80,000 & 80.000 \\
\hline Nonfederal Funds, \$ & 120,000 & 120,000 & 120.000 \\
\hline Total Funds, \$ & 200,000 & 200,000 & 200,000 \\
\hline
\end{tabular}


Project Title

Mercury Sorbent Consortium

Potential Partner(s)

Dravo Lime, Calgon, Alcoa, American Norit, and other carbon/sorbent manufacturers

Project Objective

To determine what sorbents have the best potential for mercury control for coal combustion flue gas streams.

Target Start Date

February 1, 1996

\section{Contact Person}

Dennis Laudal

Project Maturity (Check one)

Proposal submitted to commercial sponsor(s)

Ready to write proposal to commercial sponsor(s)

$\square$ Discussing with potential sponsor(s)

Developing idea internally

Basic idea exists

Applicability to Fossil Energy Objectives

Finding cheap, efficient mercury sorbents for coal combustion systems is a high priority with the U.S. Department of Energy

Fossil Energy program.

\section{Project Description}

The sorbents would be tested using a protocol that is currently being developed by the Energy \& Environmental Research Center, Radian Corporation, and Electric Power Research Institute. All sorbents would be initially tested at the bench-scale level and the most promising sorbents tested at the pilot-scale.

\begin{tabular}{|l|c|c|c|}
\hline & FY96 & FY97 & FY98 \\
\hline Federal Funds, \$ & 100,000 & 0 & 0 \\
\hline Nonfederal Funds, \$ & 150,000 & 0 & 0 \\
\hline Total Funds, \$ & 250,000 & 0 & 0 \\
\hline
\end{tabular}


Project Title

Optimizing Coal Utilization, Cleaning, and Blending at the Mine Level

Potential Partner(s)

Coal companies, utilities, and Electric Power Research Institute (consortium)

Project Objective

To develop and demonstrate an integrated system to support the optimization of fuel selection at the mine level through the following:

- Developing a system to interpret advanced and conventional coal characterization data in three dimensions and convey those results to managers, operators, and plant engineers.

- Demonstrating the ability of a data visualization system and an expert predictive system to interpolate between limited amounts of advanced characterization data.

- Integrating the currently existing coal quality algorithms for fouling, slagging, opacity, coal processing and handling, and others as a basis for determining mining, cleaning, and blending strategies of coal prior to excavation.

\begin{tabular}{|l} 
Target Start Date \\
June 1,1996 \\
\hline Contact Person(s) \\
Dave Brekke, Wes Peck, or Tom \\
Erickson \\
\\
Project Maturity (Check one) \\
$\square$ Proposal submitted to commercial \\
sponsor(s) \\
$\begin{array}{l}\text { Ready to write proposal to } \\
\text { commercial sponsor(s) }\end{array}$ \\
$\square$ Discussing with potential sponsor(s) \\
$\square$ Developing idea internally \\
$\square$ Basic idea exists
\end{tabular}

Applicability to Fossil Energy Objectives

The clean and efficient use of fossil fuel has long been the major goal of the Fossil Energy program. This project is designed to improve the efficiency of coal combustion systems by optimizing the mining, selection, cleaning, and blending of various fuels and to provide for a cleaner environment by environmentally mitigating both air and land emissions.

\section{Project Description}

This project involves the creation of a computerized system for plotting out the coal quality parameters of a coal mine and interpreting those properties for their effects on plant performance (fouling, slagging, opacity, erosion, etc.). The computer program could be used to optimize the mining strategy used to produce fuels for multiple clients and to aid in producing a better fuel through cleaning and blending strategies. The project would be broken into three tasks: analytical characterization, database, and performance indices. The project would be demonstrated at a sponsor-chosen site.

\begin{tabular}{|l|c|c|c|}
\hline & FY96 & FY97 & FY98 \\
\hline Federal Funds, \$ & 150,000 & 150,000 & 150,000 \\
\hline Nonfederal Funds, \$ & 225,000 & 225,000 & 225,000 \\
\hline Total Funds, \$ & 375,000 & 375,000 & 375,000 \\
\hline
\end{tabular}




\section{Project Title}

Fuel Quality Advisor

Potential Partner(s)

Coal companies, utilities, and Electric Power Research Institute (consortium)

\section{Project Objective}

To develop and validate an overall strategy for managing the problems associated with inorganic constituents (ash) during the combustion of coal through the following:

- Consolidate the various computer programs to predict fouling, slagging, opacity, erosion, and other problems into a single program.

- Enhance the existing models based on experimental data.

- Verify/validate these models at multiple full-scale utilities.

- Integrate an advanced data generator for providing the detailed analytical characterization necessary.

- Integrate an information management system for tracking coal quality and plant performance.

\author{
Target Start Date \\ June 1, 1996
}

Contact Person(s)

Tom Erickson, Sean Allan, or Chris

Zygarlicke

\section{Project Maturity (Check one)}

$\square$ Proposal submitted to commercial sponsor(s)

Ready to write proposal to commercial sponsor(s)

$\nabla$ Discussing with potential sponsor(s)

Developing idea internally

Basic idea exists

Applicability to Fossil Energy Objectives

The clean and efficient use of fossil fuel has long been the major goal of the Fossil Energy program. This project is designed to improve the efficiency of coal combustion systems by optimizing the selection, cleaning, and blending as well as provide for a cleaner environment by environmentally mitigating both air and land emissions.

Project Description

The various programs developed at the Energy \& Environmental Research Center (as well as other openly available models) to predict the problems associated with inorganic constituents during coal combustion will be combined into a single program. These models will be modified and enhanced based on past experimental data and data generated within the program. The models will also be integrated with a coal quality tracking system and a plant performance tracking system. The tracking systems will have the option of being integrated with the models for tuning and optimizing the models on-line. All of these components will be packaged into a powerful computer interface capable of outputting the produced information in various formats as requested by the user. The overall program will be broken into five tasks for efficient management: Interface Development, Model Integration, Experimental Support, Validation Testing, and Reporting and Management. A major thrust of this program will be to test the model on full-scale facilities to ensure acceptance of the model as fully functional at the conclusion of the project.

\begin{tabular}{|l|c|c|c|}
\hline & FY96 & FY97 & FY98 \\
\hline Federal Funds, \$ & 200,000 & 200,000 & 200,000 \\
\hline Nonfederal Funds, \$ & 300,000 & 300,000 & 300,000 \\
\hline Total Funds, \$ & 500,000 & 500,000 & 500,000 \\
\hline
\end{tabular}


Project Title

Advanced Analytical Information System

Potential Partner(s)

Utilities, coal companies, and Electric Power Research Institute

Project Objective

To develop a system for the storage, retrieval, formatting, and generation of advanced analytical information necessary for the operation of the advanced ash models being developed by the Energy \& Environmental Research Center, Electric Power Research Institute, PSI, Sandia and other organizations.

\begin{tabular}{|c|c|}
\hline \multicolumn{2}{|c|}{$\begin{array}{l}\text { Target Start Date } \\
\text { June } 1,1996\end{array}$} \\
\hline \multicolumn{2}{|c|}{$\begin{array}{l}\text { Contact Person(s) } \\
\text { Tom Erickson, Chris Zygarlicke, or Erin } \\
\text { O'Leary }\end{array}$} \\
\hline \multicolumn{2}{|c|}{ Project Maturity (Check one) } \\
\hline & $\begin{array}{l}\text { Proposal submitted to commercial } \\
\text { sponsor(s) }\end{array}$ \\
\hline & $\begin{array}{l}\text { Ready to write proposal to } \\
\text { commercial sponsor(s) }\end{array}$ \\
\hline$\theta$ & Discussing with potential sponsor(s) \\
\hline & Developing idea internally \\
\hline & Basic idea exists \\
\hline
\end{tabular}

Applicability to Fossil Energy Objectives

The clean and efficient use of fossil fuels has long been the major goal of the Fossil Energy program. Many organizations are developing advanced systems for the prediction and mitigation of ash-related problems within coal combustion systems. These advanced systems require advanced analytical information, which is scarce and variable in quality because of the development of advanced techniques over the last 5 years. Providing quality advanced analytical data for these systems will allow them to better optimize the efficiency and environmental impacts of coal combustion facilities.

Project Description

A system will be developed to allow the efficient storage and retrieval of advanced analytical information. Data currently available will be scrutinized for its inclusion in this system, and new coal samples will be analyzed as chosen by sponsors. The analytical information will include computer-controlled scanning electron microscopy, chemical fractionation, proximate-ultimate, $x$-ray fluorescence, and other information as desired by the sponsors. A system will also be integrated to generate (predict) advanced analytical information for a given geographical location and a base amount of analytical information. The project will be broken into four tasks: Database, Analytical Characterization, Advanced Data Generation, and Reporting and Management.

\begin{tabular}{|l|c|c|c|}
\hline & FY96 & FY97 & FY98 \\
\hline Federal Funds, \$ & 180,000 & 180,000 & 0 \\
\hline Nonfederal Funds, \$ & 270,000 & 270,000 & 0 \\
\hline Total Funds, \$ & 450,000 & 450,000 & 0 \\
\hline
\end{tabular}


Project Title

Field Demonstration of SPME-IR Spectroscopic Field Screening of Soil Contaminated by Hazardous Waste and Toxic Chemical Spills

Potential Partner(s)

Gas Research Institute, American Petroleum Institute, Petroleum Environmental Research Forum, Amoco, and Bomem

Project Objective

This project will demonstrate the capabilities of solid-phase microextraction (SPME) with infrared (IR) spectroscopic detection for on-site screening of soil contamination by hazardous wastes and toxic chemical spills. The proposed work will demonstrate the commercial viability of the SPME-IR field screening technique.

Target Start Date
July 1,1996
Contact Person
Ames Grisanti
Project Maturity (Check one)
$\square$ Proposal submitted to commercial
sponsor(s)
$\square$ Ready to write proposal to
commercial sponsor(s)
$\square$ Discussing with potential sponsor(s)
$\square$ Developing idea internally
$\square$ Basic idea exists

Applicability to Fossil Energy Objectives

The SPME-IR field screening technique is applicable to detection of petroleum hydrocarbons as well as chlorinated hydrocarbons and other industrial solvents and wastes generated as a result of petroleum product refining and other fossil fuelrelated industrial processes.

Project Description

The project will involve the refinement of a prototype SPME-IR device currently under development. The SPME-IR system will be laboratory-tested and be field demonstrated at a real-world site.

Refinement of the SPME-IR technique will take place during Year 1 of the proposed project. Year 2 will be a demonstration of the technology at oil and gas industry sites.

\begin{tabular}{|l|c|c|c|}
\hline & FY96 & FY97 & FY98 \\
\hline Federal Funds, \$ & 40,000 & 100,000 & 0 \\
\hline Nonfederal Funds, \$ & 60,000 & 150,000 & 0 \\
\hline Total Funds, \$ & 100,000 & 250,000 & 0 \\
\hline
\end{tabular}


Project Title

Circulating Fluidized-Bed Combustion (CFBC) of Low-Grade Fuels

Potential Partner(s)

Boiler vendors, biomass groups, and industrial boiler operators

Project Objective

The objective of the proposed work us to provide fluid-bed vendors with the information they need to competitively bid and build units to fire low-grade fuels. To accomplish this, the specific goal is to resolve operational issues related to the use of low-grade fuels in circulating fluid-bed combustion. The issues to be resolve include fouling, agglomeration, corrosion, and emissions.

\begin{tabular}{|l|}
\hline $\begin{array}{l}\text { Target Start Date } \\
\text { July } 1996\end{array}$ \\
\hline Contact Person \\
Mike Mann \\
\hline Project Maturity (Check one) \\
$\square$ Proposal submitted to commercial \\
sponsor(s) \\
$\square$ Ready to write proposal to \\
commercial sponsor(s) \\
$\square$ Discussing with potential sponsor(s) \\
$\square$ Developing idea internally \\
$\square$ Basic idea exists \\
\hline
\end{tabular}

Applicability to Fossil Energy Objectives

This project fits into the overall goals of expanding the use of U.S. technology for meeting energy needs both in the United States and abroad. It also is applicable to goals to utilize low-grade and waste fuels.

Project Description

The Energy \& Environmental Research Center has developed an extensive database on the circulating fluidized-bed combustion using a variety of coals under a consortium project that included the U.S. Department of Energy. The results from this work are highly referenced by boiler vendors and engineering firms. Two vendors have approached the Energy \& Environmental Research Center to expand the test base to waste fuels, including coal wastes, biomass, and tires. The vendors feel that they cannot bid on a number of projects because they lack information on how to design a system to deal with the problems related to these fuels. The proposed work would involve testing at the bench and pilot scale, using a suite of fuels selected by the sponsoring agencies. Operating conditions and/or design configurations would be varied to minimize the problems associated with that particular fuel. The main product would be design information and recommendations on how the selected fuels can be fired in the circulating fluidized-bed combustion.

\begin{tabular}{|l|c|c|c|}
\hline & FY96 & FY97 & FY98 \\
\hline Federal Funds, \$ & 80,000 & 120,000 & 120,000 \\
\hline Nonfederal Funds, \$ & 120,000 & 180,000 & 180,000 \\
\hline Total Funds, \$ & 200,000 & 300,000 & 300,000 \\
\hline
\end{tabular}


Project Title

Evaluation of Natural Clay Liners for Produced-Water Impoundments

Potential Partner(s)

Gas Research Institute, American Petroleum Institute, Petroleum Environmental Research Forum, and Amoco

Project Objective

Determination of the feasibility of the use of natural clay (nonsynthetic) liners for use as produced-water impoundments.

Target Start Date

April 1996

Contact Person

John Harju

Project Maturity (Check one)

Proposal submitted to commercial sponsor(s)

$\square$ Ready to write proposal to commercial sponsor(s)

$\square$ Discussing with potential sponsor(s)

Developing idea internally

Basic idea exists

Applicability to Fossil Energy Objectives

Produced water is the highest-volume waste stream generated in the oil and gas industry. Natural clay liners may provide a cost-effective barrier to the migration of produced waters.

Project Description

A facility would be constructed with leachate collection and moisture-sensing devices such that the integrity of the liner would be monitored. Periodic sampling and analyses would also be conducted on any leachate collected. The facility would be constructed by Amoco, under design criteria by the Energy \& Environmental Research Center, and all monitoring devices, sampling, etc., would be conducted by the Energy \& Environmental Research Center.

\begin{tabular}{|l|c|c|c|}
\hline & FY96 & FY97 & FY98 \\
\hline Federal Funds, \$ & 100,000 & 20,000 & 0 \\
\hline Nonfederal Funds, \$ & 300,000 & 40,000 & 0 \\
\hline Total Funds, \$ & 400,000 & 60,000 & 0 \\
\hline
\end{tabular}


Project Title

Adsorbed Natural Gas (ANG) Vehicle Fueling

Potential Partner(s)

Gas Research Institute, Northern States Power Company, Amoco, Brunswick Composites, New Flyer of America, and various activated carbon producers

Project Objective

The primary objective of this project will be to enhance the competitiveness of natural gas as a transportation fuel. Reducing the pressure of gas storage (from 3600 or 3000 psig to $500 \mathrm{psig}$ ) using specially prepared microporous carbon sorbents without greatly reducing the fuel tank volume of stored natural gas would reduce fueling equipment and vehicle fuel system component costs associated with the higher pressures.

Target Start Date

June 1, 1996

Contact Person(s)

Mark Musich or Tim Gerlach

Project Maturity (Check one)

Proposal submitted to commercial sponsor(s)

$\square$ Ready to write proposal to commercial sponsor(s)

$\square$ Discussing with potential sponsor(s)

Developing idea internally

Basic idea exists

Applicability to Fossil Energy Objectives

This project will be partially sponsored by Gas Research Institute through funds available to the U.S. Department of Energy Clean Cities program. The Energy \& Environmental Research Center is coordinating the Grand Forks Region Clean Cities Program, which enables the Energy \& Environmental Research Center to be eligible for this Gas Research Instinute backing. In keeping with U.S. Department of Energy Fossil Energy goals and objectives, the adsorbed natural gas development work seeks to broaden the end-use applications for natural gas and to advance alternative transportation fuel technology. Because fleet managers are and will continue to rely heavily on natural gas vehicles to meet requirements of the Clean Air Act Amendments of 1990 , the continued improvement of natural gas vehicle technology is of utmost importance.

\section{Project Description}

The competitiveness of natural gas vehicles could be greatly improved by reducing the costs associated with gas storage. Two hurdles facing the widespread use of natural gas vehicles are their reduced range and higher cost. The goal of this project: reduce the pressure of current gas storage (from 3600 or 3000 psig to approximately $500 \mathrm{psig}$ ) without greatly reducing the volume of stored gas using specially prepared microporous carbon sorbents. If successful, future project phases will include demonstration of an adsorbed natural gas-fueled vehicle.

Tasks to be performed include compilation of current natural gas vehicle technology and research, selection of activated carbon sorbents and natural gas vehicle fuel tanks, evaluation of the sorbent efficiency in autoclave and actual natural gas vehicle fuel tank tests, and comprehensive economic and practical comparisons of adsorbed natural gas to compressed natural gas technologies.

\begin{tabular}{|l|c|c|c|}
\hline & FY96 & FY97 & FY98 \\
\hline Federal Funds, \$ & 53,000 & 0 & 0 \\
\hline Nonfederal Funds, \$ & 80,000 & 0 & 0 \\
\hline Total Funds, \$ & 133,000 & 0 & 0 \\
\hline
\end{tabular}


Project Title

Fouling and Slagging Assessment of an Upgraded North Dakota Lignite

Potential Partner(s)

North Dakota Industrial Commission, University of Southern Illinois, and Sargent \& Lundy

Project Objective

To assess the fouling, slagging, and fly ash collection properties of a baseline ND lignite and its upgraded product. An assessment of the effects of processing on air toxics will also be performed.

\begin{tabular}{l} 
Target Start Date \\
March 1, 1996 \\
\hline $\begin{array}{l}\text { Contact Person } \\
\text { Jay Gunderson }\end{array}$ \\
\hline Project Maturity (Check one) \\
$\square \quad$ Proposal submitted to commercial \\
sponsor(s) \\
$\square$ Ready to write proposal to \\
commercial sponsor(s) \\
$\square$ Discussing with potential sponsor(s) \\
$\square \quad$ Developing idea internally \\
$\square \quad$ Basic idea exists \\
\hline
\end{tabular}

Applicability to Fossil Energy Objectives

The upgrading process is expected to reduce the sodium content, ash content, sulfur content, and moisture content of a North Dakota lignite to expand its use commercially as a fuel for power production and steam generation. High sodium, high ash, moderate sulfur, and high moisture contents in North Dakota lignites are currently impediments to penetrating the marketplace for power production as a compliance fuel.

Project Description

The Energy \& Environmental Research Center will be a subcontractor to Sargent \& Lundy and will perform the combustion tests required to assess improvements to the coal's fouling/slagging/electrostatic precipitator performance as a result of the upgrading process. The two-phase project will assess the fouling and slagging propensity for an upgraded North Dakota lignite. Drop-tube furnace tests will be used in conjunction with standard and advanced coal analyses to provide an assessment during Phase I work. Phase II work will be performed on the EERC's Combustion Test Facility to verify fouling propensity and determine effects of the upgrading process on fly ash collectibility by electrostatic precipitation. In each phase, the upgraded lignite will be compared to results obtained on the parent fuel. Eleven trace elements will be determined in the two coals and the resulting fly ash.

\begin{tabular}{|l|c|c|c|}
\hline & FY96 & FY97 & FY98 \\
\hline Federal Funds, \$ & 46,970 & 0 & 0 \\
\hline Nonfederal Funds, \$ & 70,455 & 0 & 0 \\
\hline Total Funds, \$ & 117,425 & 0 & 0 \\
\hline
\end{tabular}


Project Title

Development of a Catalyst-Coated Fabric Filter for Simultaneous $\mathrm{NO}_{x}$ and Particulate Control

Potential Partner(s)

Owens-Corning

Project Objective

The objective of the project is to demonstrate performance improvements (increased $\mathrm{NO}_{x}$ reduction and reduced ammonia slip) for a catalyst-coated fabric filter at the pilot scale. Specific goals include verifying bench-scale results achieved in the last year, $>80 \% \mathrm{NO}_{\mathrm{x}}$ reduction, and $<10 \mathrm{ppm}$ ammonia slip.

\begin{tabular}{|l|} 
Target Start Date \\
Proposal Submission: Jan.-Mar. 1996 \\
Initiate project: April-June 1996 \\
\hline $\begin{array}{l}\text { Contact Person } \\
\text { Greg Weber }\end{array}$ \\
\hline Project Maturity (Check one) \\
$\square$ Proposal submitted to commercial \\
sponsor(s) \\
$\square$ Ready to write proposal to \\
commercial sponsor(s) \\
$\square$ Discussing with potential sponsor(s) \\
$\square$ Developing idea internally \\
$\square$ Basic idea exists \\
\hline
\end{tabular}

Applicability to Fossil Energy Objectives

Current Fossil Energy objectives include reductions in emissions as specific and integral elements of new technology development. Individual program areas propose reductions in emissions of sulfur dioxide, nitrogen oxides, and particulates to levels ranging from $25 \%$ to $10 \%$ of the levels permitted by current New Source Performance Standards. In order to meet these objectives for a broad spectrum of technology applications, the development of a number of technology options will be necessary. The catalytic fabric filter concept is a technology option that can play a role in meeting the emission reduction objectives if the technology can be demonstrated to effectively control the emission of nitrogen oxides ( $>80 \%)$ and particulates (>99.95\%) with a resulting ammonia slip of $<10 \mathrm{ppm}$.

\section{Project Description}

The scope of the project will include the completion of 2 or 3 weeks of pilot-scale (130 to 150 scfm) tests to verify bench-scale $\mathrm{NO}_{\mathrm{x}}$ reduction and ammonia slip data. The scope of work may also include evaluating the durability of the catalyst-coated fabric as a function of time (several thousand hours) in a small commercial- or pilot-scale baghouse. A review of the catalytic fabric filter economics may be considered based on recent information indicating that the cost of catalyst-coated bags is only $50 \%$ of the cost used in previous estimates.

\begin{tabular}{|l|c|c|c|}
\hline & FY96 & FY97 & FY98 \\
\hline Federal Funds, \$ & 100,000 & 50,000 & 50,000 \\
\hline Nonfederal Funds, \$ & 150,000 & 125,000 & 125,000 \\
\hline Total Funds, \$ & 250,000 & 175,000 & 175,000 \\
\hline
\end{tabular}


Project Title

Utilization of Paper Mill Sludge in Pulverized Coal-Fired Boilers

Potential Partner(s)

Rainy River Corporation

Project Objective

The objective of the project is to examine the effects of combusting blends of paper mill sludge and coal in a pulverized coal-fired utility boiler. If feasible, this would result in the utilization of the waste sludge in a cost-effective and environmentally safe manner.

Applicability to Fossil Energy Objectives

This project satisfies the Fossil Energy goals and objectives in relation to broadening fossil fuel end-use applications and reducing the environmental impact of fossil fuel combustion. Improved strategies for the clean and efficient use of low-sulfur, high-calcium Powder River Basin coal in combination with a renewable fuel will result from this project. Information on the slagging, fouling, and emissions control as related to burning a Powder River Basin coal-paper mill wastepaper sludge blend will result in environmental and economic gains for the energy industry by conserving fossil fuel resources and reducing production of greenhouse gases.

Project Description

The project would involve bench-scale combustion tests of a series of blends comprised of paper mill sludge and coal. Assessment would be made of blend reactivity, fouling and slagging propensity, and emissions. Emissions measurements would focus on sulfur, chlorine, and trace elements associated with the paper sludge. The blends, as well as the fly ash and ash deposits would be characterized and predictive models used to estimate the optimum blend ratio for use.

\begin{tabular}{|l|c|c|c|}
\hline & FY96 & FY97 & FY98 \\
\hline Federal Funds, \$ & 32,000 & 0 & 0 \\
\hline Nonfederal Funds, \$ & 48,000 & 0 & 0 \\
\hline Total Funds, \$ & 80,000 & 0 & 0 \\
\hline
\end{tabular}


Project Title

Refining the Application of FT-IR Spectroscopy for Monitoring Combustor Deposits

Potential Partner(s)

Electric Power Research Institute and Clean Air Engineering

Project Objective

To determine the effects of physical characteristics of deposits on correlating Fourier transform infrared (FT-IR) spectral radiation with specific chemical species.

\begin{tabular}{|c|c|}
\hline \multicolumn{2}{|c|}{$\begin{array}{l}\text { Target Start Date } \\
\text { July } 1,1996\end{array}$} \\
\hline \multicolumn{2}{|c|}{$\begin{array}{l}\text { Contact Person(s) } \\
\text { Brian Young or Ames Grisanti }\end{array}$} \\
\hline \multicolumn{2}{|c|}{ Project Maturity (Check one) } \\
\hline & $\begin{array}{l}\text { Proposal submitted to commercial } \\
\text { sponsor(s) }\end{array}$ \\
\hline & $\begin{array}{l}\text { Ready to write proposal to } \\
\text { commercial sponsor(s) }\end{array}$ \\
\hline$\square$ & Discussing with potential sponsor(s) \\
\hline$\square$ & Developing idea internally \\
\hline & Basic idea exists \\
\hline
\end{tabular}

Applicability to Fossil Energy Objectives

Fourier transform infrared spectroscopy has potential applicability to monitoring and controlling deposit formation in coal combustion systems. Reducing the buildup of deposits in combustor convective passes will improve the efficiency and cost of operating coal-fired systems.

Project Description

Our recently completed investigation monitoring deposits in a coal-fired combustor has pointed to the need to determine the relative impacts of physical characteristics, such as layering, particle size, and surface roughness on the emission spectra arising from hot mineral deposits. Although some spectral correlations with mineral species have been made, uncertainty in data interpretation exists as a consequence of physical effects. This investigation will involve identifying the nature and extent of the physical effects to enhance the application of Fourier transform infrared spectroscopy in combustion system monitoring.

\begin{tabular}{|l|c|c|c|}
\hline & FY96 & FY97 & FY98 \\
\hline Federal Funds, \$ & 34,000 & 34,000 & 0 \\
\hline Nonfederal Funds, \$ & 50,000 & 50,000 & 0 \\
\hline Total Funds, \$ & 84,000 & 84,000 & 0 \\
\hline
\end{tabular}


Project Title

Evaluating the Efficiency of Selected Sorbents for Removing Mercury from Natural Gas Reservoirs

Potential Partner(s)

Central Environmental Inc., Gas Research Institute, and other oil and gas companies

Project Objective

To determine the efficiency of selected sorbents for removing mercury from deep-

well sources of natural gas.

\section{Target Start Date}

June 1, 1996

Contact Person(s)

Brian Young, John Harju, or Ed Olson

Project Maturity (Check one)

$\square$ Proposal submitted to commercial sponsor(s)

$\square$ Ready to write proposal to commercial sponsor(s)

$\square$ Discussing with potential sponsor(s)

$\square$ Developing idea internally

Basic idea exists

Applicability to Fossil Energy Objectives

Natural gas is increasingly being used as a clean combustion fuel. However, natural gas contains certain contaminants, in particular, mercury vapor, that need to be removed to prevent their deposition into the environment and deleterious effects on gas processing equipment.

Project Description

Selected carbon and treated inorganic sorbents have been shown to remove mercury from flue gas streams under specific conditions. The effectiveness of these materials depends on the nature of the sorbents, their pretreatment, and the constituents and the temperature of the gas stream. This project will involve simulating natural gas reservoir conditions and testing selected carbon- and silica-based sorbents for mercury uptake. The efficiency of sorption will be determined and the conditions for enhanced sorption examined.

\begin{tabular}{|l|c|c|c|}
\hline & FY96 & FY97 & FY98 \\
\hline Federal Funds, \$ & 140,000 & 140,000 & 0 \\
\hline Nonfederal Funds, \$ & 210,000 & 210,000 & 0 \\
\hline Total Funds, \$ & 350,000 & 350,000 & 0 \\
\hline
\end{tabular}


Project Title.

Development of an Infrared-Based Instrument for Measuring Combustion Deposit Thickness

Potential Partner(s)

Electric Power Research Institute, Diamond Power, and other electrical utilities

Project Objective

To develop a simple instrument based on infrared emission to measure thickness of

deposits in coal-fired combustion boiler.

Target Start Date

July 1, 1996

Contact Person(s)

Brian Young or Ames Grisanti

Project Maturity (Check one)

Proposal submitted to commercial sponsor(s)

$\square$ Ready to write proposal to commercial sponsor(s)

$\square$ Discussing with potential sponsor(s)

$\checkmark$ Developing idea internally

Basic idea exists

Applicability to Fossil Energy Objectives

Deposit buildup in coal-fired combustion boilers has deleterious effects on the combustion efficiency and is periodically, but not efficiently, controlled by sootblowers. In addition, poor control can lead to boiler tube erosion and shutdowns. The results of this project have the potential to improve the control of sootblowers and hence increase the overall energy efficiency.

Project Description

Based on recent work investigating the applicability of Fourier transform infrared spectroscopy to monitoring deposit buildup, it is planned to develop and evaluate a hand-held infrared monitor for determining the thickness of deposits in a coal-fired combustion boiler. This monitor will use the concept of ratioing the intensities of two specific wavelengths under clean and deposit-building conditions.

\begin{tabular}{|l|c|c|c|}
\hline & FY96 & FY97 & FY98 \\
\hline Federal Funds, \$ & 80,000 & 0 & 0 \\
\hline Nonfederal Funds, \$ & 120,000 & 0 & 0 \\
\hline Total Funds, \$ & 200,000 & 0 & 0 \\
\hline
\end{tabular}


Project Title

Effect of Dust Properties on Particulate Control

Potential Partner(s)

BHA Group Inc., W.L. Gore, particulate control vendors, and other fabric vendors

Project Objective

To evaluate the effect of ash properties on fine-particle collection efficiency and to develop models that relate these properties to particulate collection.

Target Start Date
May 1, 1996
Contact Person
Stan Miller
Project Maturity (Check one)
$\square$ Proposal submitted to commercial
sponsor(s)
$\square$ Ready to write proposal to
commercial sponsor(s)
$\square$ Discussing with potential sponsor(s)
$\square$ Developing idea internally
$\square$ Basic idea exists

Applicability to Fossil Energy Objectives

Relates directly to the need to minimize air toxic emissions to the atmosphere using the most economical approach.

Project Description

Project would consist of five tasks as follows:

- Collection of samples from full-scale baghouses and electrostatic precipitators

- Measurement of physical and chemical properties of ash samples

- Determine pore-bridging ability of samples in bench-scale tests

- Add new data to existing database and further develop existing models relating cohesive properties of ash to fine-particle emissions and flow resistance.

- Initiate development of a standard for quantifying cohesive properties of ash in cooperation with other groups such as American Society for Testing and Materials

\begin{tabular}{|l|c|c|c|}
\hline & FY96 & FY97 & FY98 \\
\hline Federal Funds, \$ & 80,000 & 80,000 & 0 \\
\hline Nonfederal Funds, \$ & 120,000 & 120,000 & 0 \\
\hline Total Funds, \$ & 200,000 & 200,000 & 0 \\
\hline
\end{tabular}


Project Title

Upgrading Coal Fines with Nonrecyclable Wastes

Potential Partner(s)

Coal companies, American Plastic Council, Electric Power Research Institute, North Dakota Industrial Commission, waste companies, and industrial boiler owners

Project Objective

To produce an enhanced-Btu briquetted fuel from coal fines using unrecovered nonrecyclables (contaminated paper, cardboard, plastics) as a low-cost binder and sulfur-diluting agent. The objective is to produce a usable product (briquetted fuel) from two waste materials (coal fines and nonrecyclable wastes)

\begin{tabular}{|l|}
\hline $\begin{array}{l}\text { Target Start Date } \\
\text { July } 1996\end{array}$ \\
\hline Contact Person \\
Chris Anderson \\
\hline Project Maturity (Check one) \\
$\square$ Proposal submitted to commercial \\
sponsor(s) \\
$\square$ Ready to write proposal to \\
commercial sponsor(s) \\
$\square$ Discussing with potential sponsor(s) \\
$\square$ Developing idea internally \\
$\square$ Basic idea exists \\
\hline
\end{tabular}

Applicability to Fossil Energy Objectives

This program applies to U.S. Department of Energy goals in coal upgrading and processing coal byproducts. One of the problems with many coal-upgrading facilities is fines production. Ponds of coal fines represent an environmental challenge. This project represents a method to deal with these coal-related problems while offering a partial solution to the solid-waste problems that also plague this nation.

Project Description

Both thermally treated plastic and carbonized municipal solid waste will be blended with coal fines from an operating washery(s) and fines generated from coal-drying processes. The blends will be compacted in a manually operated pellet press; the pellet feedstock will be heated as necessary to activate the residual plastic and facilitate binding during the compaction process. The prepared pellets will be subjected to chemical, mechanical, and stability analysis. One product will be selected for further evaluation in a pilot-scale stoker system. This evaluation will involve determining the combustion and environmental performance of the briquettes. A first-level engineering assessment will be made of the overall cost of this process.

\begin{tabular}{|l|c|c|c|}
\hline & FY96 & FY97 & FY98 \\
\hline Federal Funds, \$ & 40,000 & 80,000 & 0 \\
\hline Nonfederal Funds, \$ & 60,000 & 120,000 & 0 \\
\hline Total Funds, \$ & 100,000 & 200,000 & 0 \\
\hline
\end{tabular}


Project Title

Minimizing Opacity Using In-Furnace Ash Agglomeration

Potential Partner(s)

Minnesota Power, Thermal Energy Systems, Inc., and Westmoreland Resources

Project Objective

The objective of the two-phase project is to determine the effect of Thermal Energy Systems, Inc. 's in-furnace ionization system on the agglomeration of fine particulate resulting from the combustion of a Montana Powder River Basin coal at pilot scale and at full scale.

Applicability to Fossil Energy Objectives

The process is expected to improve the environmental performance, especially for fine particulate emissions, of a coal-fired utility boiler.

\section{Project Description}

The first phase will use the existing Thermal Energy Systems, Inc. ionization system developed under a separate project to evaluate the process at pilot scale. Testing will be accomplished over two 100 -hr test periods to determine the effects of various operating parameters on the agglomerating properties of the Powder River Basin fly ash. If successful, a full-scale demonstration will be performed at Minnesota Power's Clay Boswell station in Cohassett, MN. Once the full-scale system is operational, an 8-week test program may be adequate to document the full-scale performance of the ionization system.

\begin{tabular}{|l|c|c|c|}
\hline & FY96 & FY97 & FY98 \\
\hline Federal Funds, \$ & 20,000 & 100,000 & 100,000 \\
\hline Nonfederal Funds, \$ & 30,000 & 150,000 & 150,000 \\
\hline Total Funds, \$ & 50,000 & 250,000 & 250,000 \\
\hline
\end{tabular}


Project Title

Catalytic Hydrothermal Treatment for Fuel Cell Applications

Potential Partner(s)

Fuel cell vendors, coal companies, biomass groups, and municipalities

Project Objective

Hydrothermal treatment of coals, biomass, and other wastes produces a homogenous slurry fuel. However, a considerable amount of the volatiles are evolved as a gas. The objective of this project is to perform hydrothermal treatment using a catalyst to produce a gas of sufficient quality for a fuel cell in addition to a slurry fuel, thereby greatly improving the efficiency and economics of the hydrothermal treatment process.

Applicability to Fossil Energy Objectives

This project meshes with U.S. Department of Energy goals for the development of high-efficient, of modular energy systems.

\section{Project Description}

Several low-rank coals and biomass materials will be chosen for evaluation based on their propensity to generate a relatively large amount of gas during the hydrothermal treatment process. Baseline tests will qualify the amount and type of gases produced from each material. Several catalysts known to promote hydrogen formation will be tested with each material to determine the quality of fuel gas produced. The EERC will work with a fuel cell vendor to evaluate the effectiveness of the gas in their fuel cell. The fuel quality of the residual char will also be evaluated. Initial work will be performed on the autoclave. with a verification test of the most promising combination of feedstock and catalyst at the pilot level.

\begin{tabular}{|l|c|c|c|}
\hline & FY96 & FY97 & FY98 \\
\hline Federal Funds, \$ & 40,000 & 100,000 & 0 \\
\hline Nonfederal Funds, \$ & 60,000 & 150,000 & 0 \\
\hline Total Funds, \$ & 100,000 & 250,000 & 0 \\
\hline
\end{tabular}


SECTION C

\section{ADMINISTRATIVE}

pudgets removed at 


\section{ASSURANCES - NON-CONSTRUCTION PROGRAMS}

Note: Certain of these assurances may not be applicable to your project or program. If you have questions, please contact the awarding agency. Further, certain Federal awarding agencies may require applicants to certify to additional assurances. If such is the case, you will be notified.

As the duly authorized representative of the applicant I certify that the applicant:

1. Has the legal authority to apply for Federal assistance, and the institutional, managerial and financial capability (including funds sufficient to pay the non-Federal share of project costs) to ensure proper planning, management and completion of the project described in this application.

2. Will give the awarding agency, the Comptroller General of the United States, and if appropriate, the State, through any authorized representative, access to and the right to examine all records, books, papers, or documents related to the award; and will establish a proper accounting system in accordance with generally accepted accounting standards or agency directives.

3. Will establish safeguards to prohibit employees from using their positions for a purpose that constitutes or presents the appearance of personal or organizational conflict of interest, or personal gain.

4. Will initiate and complete the work within the applicable time frame after receipt of approval of the awarding agency.

5. Will comply with the Intergovernmental Personnel Act of 1970 (42 U.S.C. $\$ \S 4728-4763$ ) relating to prescribed standards for merit systems for programs funded under one of the nineteen statutes or regulations specified in Appendix A of OPM's Standards for a Merit System of Personnel Administration (5 C.F.R. 900, Subpart F).

6. Will comply with all Federal statutes relating to nondiscrimination. These include but are not limited to: (a) Title VI of the Civil Rights Act of 1964 (P.L. 88-352) which prohibits discrimination on the basis of race, color or national origin; (b) Title IX of the Education Amendments of 1972, as amended (20 U.S.C. §§ 16811683 , and 1685-1686), which prohibits discrimination on the basis of sex; (c) Section 504 of the Rehabilitation Act of 1973, as amended (29 U.S.C. § 794), which prohibits discrimination on the basis of handicaps; (d) the Age Discrimination Act of 1975, as amended (42 U.S.C. $\$ \S$ 6101-6107), which prohibits discrimination on the basis or age; (e) the Drug Abuse Office and Treatment Act of 1972 (P.L. 92-255), as amended, relating to nondiscrimination the basis of drug abuse; (f) the Comprehensive Alcohol Abuse and Alcoholism Prevention, Treatment and Rehabilitation Act of 1970 (P.L. 91-616), as amended, relating to nondiscriminat.on on the basis of alcohol abuse or alcoholism; (g) $\S \S 523$ and 527 of the Public Health Service Act of 1912 (42 U.S.C. 290 dd-3 and 290 ee-3), as amended, relating to confidentiality of alcohol and drug abuse patient records; (h) Title VIII of the Civil Rights Act of 1968 (42 U.S.C. $\$ 3601$ et seq.), as amended, relating to nondiscrimination in the sale, rental or financing of housing; (i) any other nondiscrimination provisions in the specific statute(s) under which application for Federal assistance is being made; and (j) the requirements of any other nondiscrimination statute(s) which may apply to the application.

7. Will comply, or has already complied, with the requirements of Titles II and III of the Uniform Relocation Assistance and Real Property Acquisition Policies Act of 1970 (P.L. 91-646) which provide for fair and equitable treatment of persons displaced or whose property is acquired as a result of Federal or federally assisted programs. These requirements apply to all interests in real property acquired for project purposes regardless of Federal participation in purchases.

8. Will comply with the provisions of the Hatch Act (5 U.S.C. $\S \S 1501-1508$ and 7324-7328) which limit the political activities of employees whose principal employment activities are funded in whole or in part with Federal funds.

9. Will comply, as applicable, with the provisions of the Davis-Bacon Act (40 U.S.C. $\$ \S 276 a$ to $276 a-7$ ), the Copeland Act (40 U.S.C. $\S 276 \mathrm{c}$ and 18 U.S.C. $\$ \S 874$ ), and the Contract Work Hours and Safety Standards Act (40 U.S.C. $\$ \S 327-333$ ), regarding labor standards for federally assisted construction subagreements. 
10. Will comply, if applicable, with flood insurance purchase requirements of Section 102(a) of the Flood Disaster Protection Act of 1973 (P.L. 93-234) which requires recipients in a special flood hazard area to participate in the program and to purchase flood insurance if the total cost of insurable construction and acquisition is $\$ 10,000$ or more.

11. Will comply with environmental standards which may be prescribed pursuant to the following: (a) institution of environmental quality control measures under the National Environmental Policy Act of 1969 (P.L. 91-190) and Executive Order (EO) 11514; (b) notification of violating facilities pursuant to EO 11738; (c) protection of wetlands pursuant to EO 11990; (d) evaluation of flood hazards in floodplains in accordance with EO 11988; (e) assurance of project consistency with the approved State management program developed under the Coastal Zone Management Act of 1972 (16 U.S.C. $\$ \S 1451$ et seq.); (f) conformity of Federal actions to State (Clear Air) Implementation Plans under Section 176(c) of the Clear Air Act of 1955, as amended (42 U.S.C. $\S 7401$ et seq.); (g) protection of underground sources of drinking water under the Safe Drinking Water Act of 1974, as amended, (P.L. 93-523); and (h) protection of endangered species under the Endangered Species Act of 1973, as amended, (P.L. 93-205).

12. Will comply with the Wild and Scenic Rivers Act of 1968 (16 U.S.C. $\S \S 1271$ et seq.) related to protecting components of potential components of the national wild and scenic rivers system.
13. Will assist the awarding agency in assuring compliance with Section 106 of the National Historic Preservation Act of 1966, as amended (16 U.S.C. 470), EO 11593 (identification and protection of historic properties), and the Archaeological and Historic Preservation Act of 1974 (16 U.S.C. 469a-1 et seq.).

14. Will comply with P.L. 93-348 regarding the protection of human subjects involved in research, development, and related activities supported by this award of assistance.

15. Will comply with the Laboratory Animal Welfare Act of 1966 (P.L. 89-544, as amended, 7 U.S.C. 2131 et seq.) pertaining to the care, handling, and treatment of warm blooded animals held for research, teaching, or other activities supported by this award of assistance.

16. Will comply with the Lead-Based Paint Poisoning Prevention Act (42 U.S.C. $\S \S 4801$ et seq.) which prohibits the use of lead based paint in construction or rehabilitation of residence structures.

17. Will cause to be performed the required financial and compliance audits in accordance with the Single Audit Act of 1984.

18. Will comply with all applicable requirements of all other Federal laws, executive orders, regulations and policies governing this program.

\begin{tabular}{|l|l|}
\hline SIGNATURE OF AUTHORIZED CERTIFYING OFFICIAL & \multicolumn{1}{|l|}{ TITLE } \\
\hline $\begin{array}{l}\text { APPLICANT ORGANIZATION } \\
\text { Energy \& Environmental Research Center } \\
\text { Oniversity of North Dakota }\end{array}$ & DATE SUBMITTED \\
\hline
\end{tabular}




\section{CERTIFICATIONS REGARDING LOBBYANG; DEBARMENT, SUSPENSION AND OTHER RESPONSIBILITY MATIERS; AND DRUG-FREE WORKPLACE REQUIREMENTS}

Applicants should refer to the regulations cited below to detamine the cartifiation to which they are required to atres Applieants should also review the instructons for cerifiention induded in the regulations before completing this form Sigrature of this form provides for compliance with cerifiention requiremente under 34 OFR Part 82 . New Restricsons on Lobbying and 34 GrR Part 85 , "Coverment-wide Debarment and Suspension (Nonprocurement) and Covenment-wide Requirementa for Drug-Free Workplece.

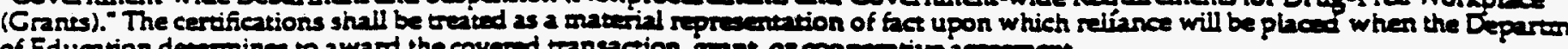
of Eduction decermines to award the covered transaction grant, or coppentive agreenent.

\section{LOBBYIVG}

As required by Secion 1352 . Title 31 of the U.S. Code, and impiemented at 34 CrR Part 82 for pesons entering into grant or cooperative agrecunent over 5100,000 , as defined at 34 EFR Par 82 Seccions 82105 and 82110 , the applicant cartifie that

(a) No Federi appropriated hunds have been paid or will be paid, by or on behalf of the undersigned, to any person for influencing or attempting to influence an officer or employe of any agency, a Member of Congres, an offices or employese of Congress, or an employee of a Member of Congrese in connecion with the onibing of any Federl gont, the entering into of any copperative agreanent, and the extension, continuation, renewal, amendment, or modification of any Federl grant or cooperative agreement;

(b) If any funds other than Foderal appropriated funds have been paid or will be paid to any peron for influencing $\alpha$ attempting to influence an offace or employee of any agency, a Member of Congrese, an officas or employes of Congrese, or an enployes of a Member of Congrese in connection with this Federal grant or cooperative agrement, the undersigned shall complete and subonit Standard Form - LLL, Disclosure Form to Report Lobbying " in acosondance with is insteractions;

(c) The undersigned shall require that the language of this certification be included in the award documents for all subawards at all tiers (ineluding subgonts, controces under grants and cooperative agreements, and subcontracs) and that all subrecipienis shall certify and dieclose accordingiy.

\section{DEBARMENT, SUSPENSION, AND OTHER RESPONSTBRTIYMATIERS}

As required by Executive Onder 12549. Debarment and Suspersion, and implemented at 34 C7R Part 85, for prospective participants in primary coverd transaceions, as derined at 34 CFR Part 85, Secion 85.105 and 85.110 -

\section{A. The applient cerifies that it and its prineipais:}

(a) Are not presenty debarsed, suppended, proposed for debarment, declared ineligible, or voluntarily exeluded from covered transactions by any Federl department or agangy,

(b) Have not within a throyer period pracoding this application been convicted of or had a civil judgoment randend ageinst theen for commission of fraud or a criminal offense in connection with obtining, attempting to obtain, or performing a public Federal State or local sansaction or contrea under a public transaction; violation of Federi or Sate antiturst santes or commiavion of enberlement, theft, forgery. bribery, falsificaion or destruction of records, making false statements, or receiving seolen property;

(c) Are not presenty indicted for or cherwise eininally or civilly charged by a goverumeneal entity federal, Sate or local) with commission of any of the offenses enumerated in pargraph (2)(b) of this cerification; and (d) Have noe within a three-year period preceding this appliention had one or more public rnngecions (federl, $S$ or loen terminated for cuse or defiut; and

B. Where the applicant is unable to certify to any of the sertements in this certifieation, he or she shail arsech an epplanation to this appliation.

\section{DRUG-FREE WORXPLACE (GRANTEES OTHER THLN INDTVIDUAIS)}

As required by the Drag-Free Workphas Aet of 1988, and implementad at 34 CFR Part 85, Subpart F, for grantees, as defined at 34 CRR Part 85, Sections 85.605 and 85610 -

A. The applient cartifes that it will or will continue to provide a drug-free worikplace oy:

(a) Publining a statement notifying eaployes that the unlawful manufacure, distribution, dispensing posescios use of a controlled subsence is prohibited in the granteds workplace and spe-ifying the accions that will be then ag enployees for violation of such prohibition;

(b) Exblishing an on-going drug-tree awarenes progran inform employeces about-

(1) The dangers of drug abuse in the worisplace;

(2) The grantex's policy of maintaining a drug-tres workpli

(3) Any avainble drug counseling, rehabilitation, and enployes astictnce progonom; and

(4) The penalies that may be inposed upon employes for drug abuse violations cosurring in the workplace;

(c) Making it a requirement that ench employes to be engal in the performance of the gonn be given a copy of the sentedient required by pargonph (a);

(d) Notifying the employee in the statemert required by paragaph ( $\mathrm{S}$ that, as a condition of employmert under th grant, the employee will-

(1) Abide by the terens of the statement; and

(2) Notify the employer in writing of his or her conviction violation of a aininal drug stature coruring in the wortp no later than five ealendar days after such conviction:

(c) Nobfying the agency, in writing, within 10 olendar da after reciving nower under subpargorph (dX) from an eoployes of cherwier receiving actul notice of such conviction. Employes of convicted employees muet prov notice including position title, bires: Dr, Crants and Contence Savice, US. Departenent of Eduacion, 100 Mayiand Avenue, S.W. (Room 3124 CSA Regional Office 
Building No. 37, Wahington, DC 20202 4571. Notes shall inducte the identifietion number(s) of ench affect grant:

() Taking one of the following actions, within 30 evlandar days of receiving notice under subparagraph (d)(0), with respet to any employe who is so conviosed-

(I) Taking appropriate pasonnd action aginte such an enployee up to and induding termination, consirtent with the requiremens of the Rehabilitition Ace of 1973, as anended; or

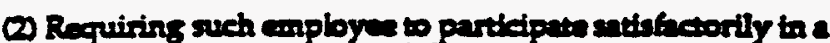
drus abuse astistence or rehbilitation propon approved for such purpowes by a Fuderal, Steres or locl henith, law enforecrient or other approprinte agency.

(o) Making a good fith ffort to continue to mainth a drug-free workplece through implenentation of parafaphs $(a),(b),(c),(d),(c)$, and (o).

B. The grames moy incert in the space provided balow the situ(s) for the performance of work don in connection with the specific grant

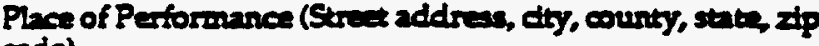
codel

15 North 23rd Street

Grand Forks, Grand Forks County, North Dakota

58202

\section{DRUGRREE WORTPLACE (GRANTEES WHO ARE INDTVTOUAIS)}

As required by the Drug-Free Workplace Act of 1988, and

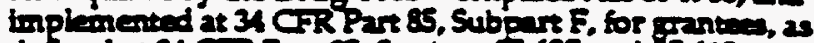
defined at 34 CFR Part 85, Sactons 85605 and 85.610 -

A. An a condition of the gant, I certify that I will nox engage: the uniawful mamuface, diveribution, dispensing, posacaion, or use of a contolled subsenncs in conducting any acivity with the grant; and

B. If conviated of a criminal drug offense resulting from a violation oesurving during the conduct of any gont activity, I will report the conviction in writing, within 10 elendar days of the convistion tx. Dir-ter. Grints and Contraces Service. US Department of Eduetion, $100 \mathrm{M}$ aryland Avenues S.W. Room 3124, CSA Reponal Ofice Building No. 3). Washingtor DC $20082-1571$. Notice shall indude the identifiation number(s) of ench affected grant.

Check $\square$ if there are wortplaces on ale that are act identifed

here.

As the duly authortad representative of the applient, I benty cattify that the applient will comply with the above catifications.

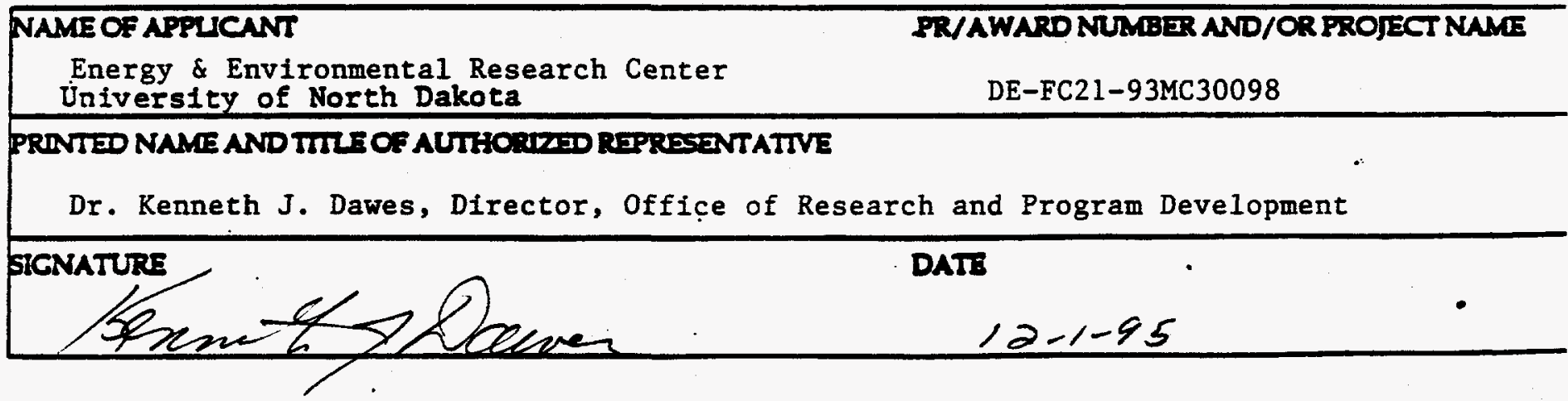



(See reverse for public burden disclosure.)

1. Type of Federal Actions
a. contract
b. grant
c. cooperative agreement
d. loan
e. Ioan guarantee
f. Joan insurance

\section{Stutus of Federal Action:}

a. bid/offerfapplication

b. initid award

c. post-award

\section{Report Type: \\ a. Initid filing \\ b. material change \\ For Material Change Only. \\ year date of last report}

4. Name and Address of Reporting Entity:

Ex Prime

Subawardee

Tier if known:

University of North Dakota

Energy \& Environmental Research Center Box 9018

Grand Forks ND 58202

5. If Reporting Entity in No. 4 is Subawardee, Enter Name and Address of Prime:
Congressional District if known:

6. Federal Department/Agency:

United States Department of Energy

8. Federal Action Number, if known:

10. 2. Name and Address of Lobbying Entity (If individual, last name, first name, MI):

Greystone Group

Sara Garland Associates

312 Mass Ave NE

Washington DC 20002

Garland, Sara

Congressional District, if known:

7. Federal Program Name/Description:

Jointly Sponsored Research Program

Continuation Application

CFDA Number, if applicable: $\frac{81,089}{8}$

9. Award Amount, if known:

$52,500,000.00$

b. Individuals Performing Services (including address if different from No. 10a)

(last name, first name, MI):

(attach Continuation Sheet(s) SF-UL -A if necessany)

11. Amount of Payment (check all that apply):
s $200.00 /$ month
Đ actual
planned

12. Form of Payment (check all that apply):

a. cash
$\square$ b. in-kind; specify: nature

value

13. Type of Payment (check all that apply):
a. retainer
b. one-time fee
a c. commission
a d. contingent fee
a e. deferred
1. other; specify:

14. Brief Description of Services Performed or to be Performed and Date(s) of Service, including officer(s), employee(s). or Member(s) contected for Payment Indicated in Item 11:

see attached

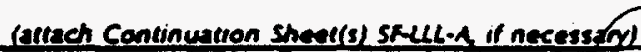

\section{Continuation Sheet(s) SF-UL.A attached: $\square$ Yes}

16. Information requested throwh this form is withorized by bite 31 U.S.C. wetion 1352. This discloure of bebying activitios is a material mposentation of tact upon whech retience wa pluced by the ties above when thes teansuction was mate of entered into. Thu disclesure is required purwent to 31 U.S.C. 1352. Inis information will be reported to the Congress semir annustly and will be aveilablo for public inepoction. Any ponon who figh to

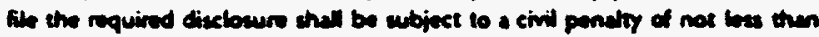

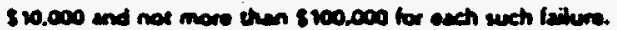

$\square$ No Signature:

Print Name: Lyle Beiswenger

Title: Vice President for Finance

Telephone No.: (701) 777-41510ate: 1? 1 -1-95 
Pase 2 ol

University of North Dakota lobbying activity relating to the Department of Energy Joint Venture Agreement consisted of meetings with the North Dakota Congressiional delegation and their staffs, meetings with House and Senate Appropriations Committee staff, and conversations with officials at the Department of Energy. Information was provided to these individuals describing activities resulting from prior year appropriations for this initiative.

Lobbying activity was initiated and continued thronghout the consideration of the Fiocal Year 1996 Interior Appropriations legislation, commencing in February 1995, and will conclude with the enactment into law of this legislation.

Contacts included the following individuals:

Senator Byron Dorgan

Senator Kent Conrad

Congressman Earl Pomeroy

Dong Norell, aide to Sen. Dorgan

Allen Huffman, aide to Sen. Dorgan

Niles Godes, aide to Sen. Conrad

Craig May, aide to Sen. Conrad

Kent Hall, aide to Sen. Conrad

Bart Chilton, aide to Rep. Pomeroy

Mike Smart, aide to Rep. Pomeroy

Bruce Evans, Senate Appropriations Committee

Sue Masien, Senate Appropriations Commitiee

Loretta Beanmont, House Appropriations Committee

Barbara Wainman, aide to Rep. Ralph Regula 


\section{OMB Burden Disclosure Statement}

Public reporting for this collection of inforomation is estimated to average 15 minutes per response, including the time for reviewing instructions, searching existing data sources, gathering and maintaining the data needed and completing and reviewing the collection of information. Send comments regarding this burden estimate or any other aspect of this cillection of information, including suggestions for reducing this burden to Office of Information Resources Management Policy, Plans, and Oversight; Records Management Division, HR-422-GTN, Paperwork Reduction Project (1910-0400), U.S. Department of Energy, 1000 independence Avenue, S.W., Washington, DC 20585, and to the Office of Management and Budget (OMB), Paperwork Reduction Project (191004001 , Washington, D.C. 20503.

University of North Dakota

(Hereinafter called the "Applicant") HEREBY AGREES to comply with Title VI of the Civil Rights Act of 1964 (Pub. L. 88-352), Section 16 of the Federal Energy Administration Act of 1974 (Pub. L. 93-275). Section 401 of the Energy Reorganization Act of 1974 (Pub. L. 93-438), Title IX of the Education Amendments of 1972 as amended (Pub. L. 92-318, Pub L. 93-588 and Pub L. 94-482), Section 504 of the Rehabilitation Act of 1973 (Pub. L. 93-112), the Age Discrimination Act of 1975 (Pub. L. 94-135), Title VIII of the Civil Rights Act of 1968 (Pub. L. 90-284), the Department of Energy Organization Act of 1977 (Pub. L. 95-91), and the Energy Conservation and Production Act of 1976 as amended (Pub. L. 94-385). and Title 10, Code of Federal Regulations, Part 1040. In accordance with the above laws and regulations issued pursuant thereto. the Applicant agrees to assure that no person in the United States shall on the ground of race, color, national origin, sex, age, or handicap be excluded from participation in, be denied the benefits of, or be otherwise subjected to discrimination under any program or activity in which the Applicant receives Federal assistance from the Department of Energy.

\section{Applicability and Period of Obligation}

In the case of any service, financial aid, covered employment, equipment, property, or structure provided, leased, or improved with Federal Assistance extended to the Applicant by the Department of Energy, this assurance obligates the Applicant for the period during which Federal Assistance is extended. In the case of any transfer of such service, financial aid, equipment, property, or structure, this assurance obligates the transferee for the period during which Federal assistance is extended. If any personal property is so provided, this assurance obligates the Applicant for the period during which it retains ownership or possession of the property. In all other cases this assurance obligates the Applicant for the period during which the Federal assistance is extended to the Applicant by the Department of Energy.

\section{Employment Practices}

Where a primary objective of the Federal assistance is to provide employment or where the Applicant's employment practices affect the delivery of services in programs or activities resulting from Federal assistance extended by the Department, the Applicant agrees not to discriminate on the ground of race, color, national origin, sex, age, or handicap in its employment practices. Such employment practices may include, but are not limited to, recruitment, recruit advertising, hiring, layoff or termination, promotion, demotion, transfer, rates of pay, training, and participation in upward mobility programs or other forms of compensation and use of facilities.

\section{Subrecipient Assurance}

The Applicant shall require any individual, organization, or other entity with whom it subcontracts, subgrants, or subleases for the purpose of providing any service, financial aid, equipment, property, or structure to comply with laws cited above. To this end, the subrecipient shall be required to sign a written assurance form, however, the obligation of both recipient and subrecipient to ensure compliance is not relieved by the collection or submission of written assurance forms.

\section{Data Collection and Access to Records}

The Applicant agrees to compile and maintain information pertaining to programs or activities developed as a result of the Applicant's receipt of Federal assistance from the Department of Energy. Such information shall include, but is not limited to the following: (1) the manner in which services are or will be provided and related data necessary for determining whether any persons are or will be denied such services on the basis of prohibited discrimination; (2) the population eligible to be served by race, color, national origin, sex, age, and handicap; (3) data regarding covered employment including use or planned use of bilingual public contact employees serving beneficiaries of the program where necessary to permit effective participation by beneficiary unable to speak or understand English; (4) the location of exsisting or proposed facilities connected with the program and related information adequate for determining whether the location has or will have the effect of unnecessarily denying access to any person on the basis of prohibited discrimination; (5) the present or proposed membership by race, color, national origin, sex, age, and handicap in any planning or advisory body which is an integral part of the program; and (6) assure compliance by recipients with laws cited in the first paragraph of this assurance. 
The Applicant agrees to submit requested data to the Department of Energy regarding programs and activities developed by the Applicant from the use of Federal assistance funds extended by the Department of Energy. Facilities of the Applicant (including the physical plants, buildings, or other structures) and all records, books, accounts, and other sources of information pertinent to the Applicants compliance with the civil rights laws shall be made available for inspection during normal business hours on request of an officer or employee of the Department of Energy specifically authorized to make such inspections. Instructions in this regard will be provided by the Directors Office of Equal Opportunity, U.S. Department of Energy.

This assurance is given in consideration of and for the purpose of obtaining any and all Federal grants, loans, contracts lexcluding procurement contracts), property discounts, or other Federal assistance extended after the date hereto, to the Applicants by the Department of Energy, including installment payments on account after such data of application for Federal Assistance which are approved before such date. The Applicant recognizes and agrees that such Federal assistance will be extended in reliance upon the representations and agreements made in this assurance and that the United States shall have the right to seek judicial enforcement of this assurance. This assurance in binding on the Applicant, its successors, transferees, and assignees, as well as the persons whose signatures appear below and who are authorized to sign this assurance on behalf of the Applicant.

\section{Applicant Certification}

The Applicant certifies that it has complied, or that, within 90 days of the date of the grant, it will comply with all applicable requirements of 10 C.F.R. $\$ 1040.5$ (a copy will be furnished to the Applicant upon written request to DOE).

Designated Responsible Employee

Dr. Kenneth J. Dawes, Director

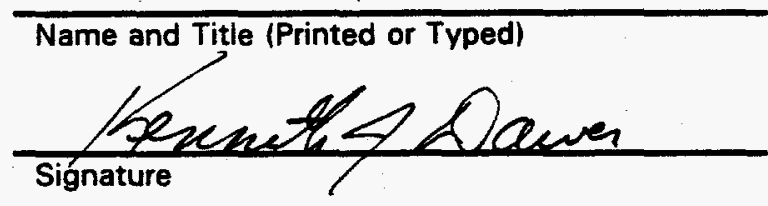

Energy \& Environmental Research Center

University of North Dakota

Applicant's Name

15 North 23rd Street

Grand Forks, North Dakota 58202
( 701$) 777-4278$

\begin{tabular}{l} 
Telephone Number \\
\hline $2-1-\$ 5$ \\
Date
\end{tabular}

(701) 777-5000

Telephone Number

Address 


\title{
PRE-AWARD PATENT INFORMATION SHEET
}

\author{
AGREEMENT NO.: \\ AMENDMENT NO.:
}

\section{THE PARTICIPANT IS:}

X A University or other institution of higher education or an organization of the type described in section 501 (c) (3) or the Internal revenue Code of 1954 (26 USC 501 (c)) and exempt form taxation under section 501 (a) of the Internal Revenue Code (26 USC 501 (a)); or

A nonprofit scientific or educational organization qualified under a State nonprofit organization statute. Please identify the statue.

A small business concern as defined at section 2 of Public Law 85-536 (15 USC 632) and implementing regulations of the administrator of the Small Business Administration.

None of the above

Participants who have checked NONE OF THE ABOVE have the right to request, in advance of or within 30 days after execution of the cooperative agreement, in accordance with applicable statutes and DOE Procurement Regulations (9-9.109-6), a waiver of all or any part of the rights of the United States in Subject Inventions. If the Participant intends to request a Waiver to such invention rights pursuant to DOE PR 9-9.109-6, please indicate:

We intend to request an advance waiver in accordance with DOE PR 9-9.109-6.

We do not intend to request an advance waiver.

\section{RIGHTS IN PROPOSAL DATA}

It is DOE policy for a cooperative agreement award based on a proposal that, in consideration of the award, the Government shall obtain unlimited rights in the technical data contained in the proposal unless the participants marks those portions of the technical information which he asserts as "proprietary data" or specifies those portions of such technical data which are not directly related to or will not be utilized in the work to be funded under the cooperative agreement. Accordingly, please indicate:

Wo restriction on Government rights in the proposal technical data; or

The following identified technical data is proprietary or is not directly related to or will not be utilized in the work to be funded under the cooperative agreement: 


\section{IDENTIFICATION OF TECHNICAL DATA WHICH IS PROPRIETARY}

The Rights in Technical Data clause proposed to be used for this cooperative agreement may not permit the utilization of proprietary data in the agreement work or, if the use of proprietary data is permitted, may not be adequate to meet programmatic requirements. Use of data which is proprietary may prevent you from meeting the data requirements of the agreement (including delivery of data). Your attention is particularly drawn to the use of LICENSED COMPUTER SOFTWARE.

Please indicate that you have reviewed the requirements in the technical scope of work and to the best of your knowledge:

$\bigotimes$ No proprietary data will be utilized.

Proprietary data as follows will be utilized:

$\bigotimes$ No LICENSED COMPUTER SOFTWARE will be utilized.

LICENSED COMPUTER SOFTWARE as follows will be utilized:

University of North Dakota

Organization Name
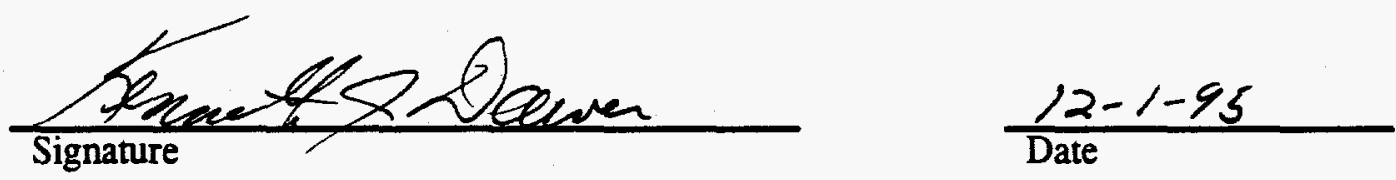

Dr. Kenneth J. Dawes, Director Office of Research and Program Development

Name and Title of Authorized Representative 